\title{
A Single Microorganism Epitope Attenuates the Development of Murine Autoimmune Arthritis: Regulation of Dendritic Cells via the Mannose Receptor
}

\author{
Fan Yang, Xuemei Fan, He Huang, Qiujie Dang, Hongwei Lei and Yang Li* \\ Department of Rheumatology and Immunology, The Second Affiliated Hospital of Harbin Medical University, Harbin, China
}

OPEN ACCESS

Edited by:

Laurence Morel,

University of Florida,

United States

Reviewed by:

Carla Marie Cuda,

Northwestern University,

United States

Stefania Gallucci,

Temple University,

United States

*Correspondence:

Yang $L$

liyang@hrbmu.edu.cn

Specialty section: This article was submitted to

Autoimmune and

Autoinflammatory Disorders,

a section of the journal

Frontiers in Immunology

Received: 15 March 2018

Accepted: 20 June 2018

Published: 02 July 2018

Citation:

Yang $F$, Fan X, Huang $H$, Dang $Q$,

Lei H and Li Y (2018) A Single

Microorganism Epitope Attenuates

the Development of Murine

Autoimmune Arthritis: Regulation of

Dendritic Cells

via the Mannose Receptor.

Front. Immunol. 9:1528.

doi: 10.3389/fimmu.2018.01528
A single epitope of Leishmania analog of the receptors for activated $C$ kinase (LACK) from Leishmania major, the polypeptide $L A C K_{156-173}$, is recognized by $V \beta 4^{+} N \alpha 8^{+} T$ cells, and activate these cells that drives the subsequent $T$ helper (Th)2 response. This study was undertaken to investigate the therapeutic potential of the LACK ${ }_{156-173}$ epitope in murine autoimmune arthritis models. To explore the influence of the LACK ${ }_{156-173}$ epitope on murine collagen antibody-induced arthritis, as well as its immunological mechanism, we vaccinated or treated mice with a LACK $K_{156-173}$ epitope expression plasmid or polypeptide. The effect of $L A C K_{156-173}$ epitope was then evaluated by clinical scores, histopathology, and quantitative real-time polymerase chain reaction (qRT-PCR) analysis. Using flow cytometry, we measured the subsets and maturity of CD11 $\mathrm{c}^{+}$dendritic cells (DCs), as well as $T$ cell polarization, in co-culture experiments. We also measured cytokine gene expression and production. The murine macrophage-like cell line RAW264.7 was used to identify the receptor for the epitope. Vaccination or treatment of the mice with the LACK $_{156-173}$ epitope expression plasmid or polypeptide ameliorated the severity of arthritis. QRT-PCR analysis revealed that the $L_{A C K_{156-173}}$ epitope improved the balance of effector T cells in synovial tissue compared to that in untreated arthritis controls. Toll-like receptor (TLR) 4 expression was diminished by LACK ${ }_{156-173 .}$. The epitope also influenced $T$ cell polarization by regulating the differentiation, maturation, and functions of $C D 11 \mathrm{C}^{+}$ DCs and upregulating Jagged 1 ligand expression. Blocking the mannose receptor (MR) significantly attenuated $L A C K_{156-173}$ epitope-induced macrophage activation. Our data indicate that vaccination or treatment with a single microorganism epitope, LACK $_{156-173}$, is a highly efficient therapy for murine autoimmune arthritis. The therapeutic effects are mediated by the regulation of the differentiation, maturation, and functions of DCs via MR, resulting in the upregulation of Jagged1 expression and Th2 cell polarization. Our results demonstrate the therapeutic potential of the $L_{A C K_{156-173}}$ epitope in rheumatoid arthritis.

Keywords: arthritis, Leishmania major, dendritic cells, Jagged1, mannose receptor 


\section{INTRODUCTION}

Rheumatoid arthritis (RA) is a chronic autoimmune disease characterized by synovitis and bone destruction; it leads to substantial disability. RA affects approximately $1 \%$ of the global population. Although the exact pathogenesis of RA remains unclear, T cellmediated adaptive immunity is deeply involved in the initiation and progression of RA (1). T helper (Th) 1 and Th17 subsets of $\mathrm{CD}^{+} \mathrm{T}$ cells, and the pro-inflammatory cytokines they produce, play critical roles in the pathogenesis of RA (2). However, Th2 immune responses and regulatory $\mathrm{T}$ cells have protective effects in RA $(3,4)$. Therefore, the regulation of $\mathrm{T}$ cell responses is an important new treatment strategy in RA.

The "hygiene hypothesis," which proposes that improvements in public health in the developed world may be causing a rise in the prevalence of autoimmune diseases, has been recognized for two decades (5). This theory has been strengthened by solid epidemiological, experimental, and clinical data, which have paved the way for the development of future therapies. Infections may protect from autoimmune diseases. This paradoxical effect has been demonstrated for a number of bacteria, viruses, and parasites in a variety of spontaneous or experimentally induced animal models of autoimmune diseases (e.g., in animal models of experimental autoimmune encephalomyelitis and inflammatory bowel disease, and in non-obese diabetic mice) (6-11). Some microorganisms skew the immune system toward Th2 responses, and/or the production of interleukin (IL)-4, IL-13, IL-5, and IL-10. Both Th1 and Th17 inflammatory responses and cytokine (TNF- $\alpha$, IFN- $\gamma$, IL-6, IL-12, and IL-17) secretion are inhibited by parasite infections. Some microorganisms also promote a regulatory phenotype of $\mathrm{B}$ cells, dendritic cells (DCs), and macrophages. Tolerogenic DCs and regulatory M2 macrophages could all contribute to switching from a Th1/Th17 response to a Th2/Treg profile $(12,13)$. Therefore, it is a growing and exciting strategy regarding the key role played by microorganisms in autoimmunity.

LACK, the Leishmania analog of the receptors for activated C kinase, is an important antigen from Leishmania major (14). A single epitope of the LACK protein, polypeptide LACK $_{156-173}$, can be recognized by $\mathrm{V} \beta 4^{+} / \mathrm{V} \alpha 8^{+} \mathrm{T}$ cells, thereby driving the cells into a Th2 response in susceptible $\mathrm{BALB} / \mathrm{c}$ mice. The aberrant development of Th2 cells instead of Th1 cells in response to infection renders $\mathrm{BALB} / \mathrm{c}$ mice unable to control parasite dissemination (15-17). However, the Th2-polarizing epitope may have therapeutic potential in autoimmune diseases. In the present study, we analyzed the effects of the $\mathrm{LACK}_{156-173}$ epitope in murine autoimmune arthritis models, and the influence on DC subsets and $\mathrm{T}$ cells $(18,19)$, to determine the therapeutic potential for autoimmune arthritis.

\section{MATERIALS AND METHODS}

\section{Mice}

We used female BALB/c mice (6-8 weeks old and 16-24 weeks old) and male DBA/1 mice (8-10 weeks old). The mice were purchased from the Experimental Animal Center of The Second
Affiliated Hospital of Harbin Medical University. All mice were housed under a 12-h light/12-h dark cycle in a temperature- and humidity-controlled room.

\section{Arthritis Induction and Assessment Induction of Murine Arthritis Models}

Collagen antibody-induced arthritis (CAIA) was induced in female BALB/c mice (6-8 weeks old) by tail vein injection of $1.5 \mathrm{mg}$ anti-type II collagen 5-clone monoclonal antibody (mAb) cocktail (Chondrex, Redmond, WA, USA) on day 0. On day 3, mice received an intraperitoneal (i.p.) injection of $25 \mu \mathrm{g}$ lipopolysaccharide (LPS; Chondrex, Redmond, WA, USA). The mice were scored daily after the injection of the mAb until day 14 .

Proteoglycan (PG)-induced arthritis (PGIA) was induced in female BALB/c mice (16-24 weeks old) via 3 i.p. injections of $100 \mu \mathrm{g}$ bovine PG (Sigma-Aldrich, St. Louis, MO, USA) emulsified in $1 \mathrm{mg}$ dimethyldioctadecylammonium bromide (DDA) (Sigma-Aldrich, St. Louis, MO, USA) adjuvant at intervals of 21 days. After the third injection, the mice were scored daily and evaluated until 70 days after the first injection.

Collagen-induced arthritis (CIA) was induced in DBA/1 mice. Briefly, bovine collagen II (CII) solution $(2 \mathrm{mg} / \mathrm{ml}$ in $0.05 \mathrm{M}$ acetic acid) (Chondrex, Redmond, WA, USA) was emulsified with an equal volume of Freund's complete adjuvant (Chondrex, Redmond, WA, USA). On day 0, we subcutaneously (s.c.) injected $0.1 \mathrm{ml}$ of the emulsion at the base of the mouse tail. On day 21, a booster injection $(0.1 \mathrm{ml} \mathrm{CII} \mathrm{emulsified} \mathrm{with} \mathrm{Freund's} \mathrm{incomplete}$ adjuvant) was administered near the primary injection site. After the booster injection, the mice were scored daily until 50 days after the beginning of arthritis induction.

\section{LACK $_{156-173}$ Epitope Vaccination and Treatment}

The LACK $_{156-173}$ peptide (ICFSPSLEHPIVVSGSWD, rLACK) and the LACK-K164 mutant peptide (ICFSPSLEKPIVVSGSWD, LACK-K), with the designated alteration of $\mathrm{H}$ at position 164, were synthesized by Geni Biotechnology Company (Shanghai, China). The purity of the peptides was greater than $95 \%$.

The recombinant $\mathrm{LACK}_{156-173}$ polypeptide expression plasmid pLACK was synthesized by Shanghai CPG Biotech Company and the target gene was sub-cloned into the eukaryotic expression vector pcDNA3.1(+). The plasmid was amplified in TOP10 Escherichia coli competent cells. The plasmids were purified in large quantities using EndoFree ${ }^{\circledR}$ Plasmid Maxi Kit (QIAGEN, Hilden, Germany). The presence of the target oligonucleotides was confirmed by DNA sequencing.

Collagen antibody-induced arthritis mice were vaccinated 7 days before $\mathrm{mAb}$ injection, with either plasmid or peptide. The mice in the treatment groups were injected with plasmid or peptide on day 4 after $\mathrm{mAb}$ injection. PGIA mice were treated with peptide after the third injection of PG with 7-day interval. CIA mice were treated with peptide after the booster injection with 7-day interval.

The plasmid-vaccinated or -treated mice were injected with $50 \mu \mathrm{l}$ bupivacaine $(0.25 \%)$ in each quadriceps. Then, $24 \mathrm{~h}$ later, mice were injected intramuscularly with $50 \mu \mathrm{g}$ pLACK $(1 \mu \mathrm{g} / \mu \mathrm{l})$ or pcDNA3.1(+) per leg in the same place (20). The peptidevaccinated or -treated mice were injected s.c. in the foot pad 
with $25 \mu \mathrm{g}$ rLACK $(1 \mu \mathrm{g} / \mu \mathrm{l})$ or LACK-K on each side. The mice injected with PBS were used as the control group.

\section{Clinical and Histological Assessment of Arthritis}

The severity of arthritis in all four paws was graded independently on a $0-4$ scale for each paw: $0=$ no swelling; $1=$ mild erythema or swelling of the wrist or ankle, or erythema and swelling of any severity for one digit; $2=$ more than three inflamed digits, or moderate erythema and swelling of the ankle or wrist; $3=$ severe erythema and swelling of the wrist or ankle; and $4=$ complete erythema and swelling of the wrist and ankle, including all digits.

Limbs of the mice from each group were gotten on the day of sacrifice, which fixed in $10 \%$ neutral formalin, decalcified in 15\% EDTA solution, and embedded in paraffin. Serial sections were prepared and stained with hematoxylin and eosin.

\section{Real-Time Polymerase Chain Reaction}

The patella and adjacent synovial tissue were dissected from euthanized animals, and ground in liquid nitrogen. Total RNA was isolated using TRIzol ${ }^{\mathrm{TM}}$ reagent. Complementary DNA was synthesized from total RNA using AccuPower ${ }^{\circledR}$ RocketScript $^{\mathrm{TM}}$ RT Premix (Bioneer, Daejeon, Korea). For the detection of gene transcripts, quantitative real-time polymerase chain reaction (qRT-PCR) was carried out with the AccuPower ${ }^{\circledR} 2 \mathrm{X}$ SYBR ${ }^{\circledR}$ Green I qPCR Master Mix (Bioneer, Daejeon, Korea). The mRNA expression was normalized to that of housekeeping genes (Actb and Gapdh) by the threshold cycle $(\Delta \Delta \mathrm{CT})$ method.

\section{Serum Analyses}

Anti-LACK ${ }_{156-173}$ epitope antibodies in the serum were quantified by enzyme-linked immunosorbent assay (ELISA). In brief, 96-well plates were coated overnight at $4^{\circ} \mathrm{C}$ with $10 \mu \mathrm{g} \mathrm{rLACK} / \mathrm{ml}$ in PBS. We washed the plates with Tris-buffered saline ( $\mathrm{pH} 7.4$ ) containing $0.1 \%$ TWEEN $^{\circledR} 20$. The sera were tested in duplicate. The amounts of bound IgG antibodies were determined after incubation with polyclonal goat anti-mouse IgG $\mathrm{mAb}$ conjugated to horseradish peroxidase. TMB (Sigma-Aldrich, St. Louis, MO, USA) was used as the chromogenic substrate and absorbance was measured at $450 \mathrm{~nm}$ with a Multiskan ${ }^{\mathrm{TM}}$ Spectrum Microplate reader (Thermo Scientific, Carlsbad, CA, USA).

\section{Analysis of the Phenotypes of DCs and the In Vitro Polarization of T Cells From CAIA Mice}

Single-lymphocyte suspensions from the spleens of CAIA mice were generated by mechanical disruption and red blood cell lysis 7 days after $\mathrm{mAb}$ injection. $\mathrm{LACK}_{156-173}$ epitope-derived $\mathrm{CD} 11 \mathrm{c}^{+}$ DCs were purified from the splenocytes of CAIA mice by magnetic cell sorting (Miltenyi, Teterow, Germany). The expression of the surface molecules on the DCs was measured by flow cytometry.

For the polarization of $\mathrm{T}$ cells in vitro, $\mathrm{LACK}_{156-173}$ epitopederived CD $11 \mathrm{c}^{+} \mathrm{DC}$ s were co-cultured with T cells at a DC:T cell ratio of 1:10. The $\mathrm{T}$ cells were isolated by passing splenocytes, from $\mathrm{BALB} / \mathrm{c}$ mice that had been i.p. injected with $100 \mu \mathrm{g}$ OVA $_{323-339}$ (Sigma-Aldrich, St. Louis, MO, USA) 7 days prior, through nylon wool fiber in a syringe. The cells were cultured in 24-well culture plates $\left(2 \times 10^{6} / \mathrm{ml}\right)$ in RPMI-1640 supplemented with $10 \%$ fetal bovine serum (FBS) and $\mathrm{OVA}_{323-339}(15 \mu \mathrm{g} / \mathrm{ml})$ for $72 \mathrm{~h}$. The mRNA expression of cytokines and the differentiation of T cells were measured by qRT-PCR and flow cytometry, respectively. We also tested the concentrations of cytokines in the culture supernatants.

\section{Analysis of T Cell Polarization Induced by Targeting Jagged1 Expression in DCs}

Bone marrow-derived dendritic cells (BMDCs) generation: bone marrow cells from the tibiae and femurs of BALB/c mice were cultured with granulocyte-macrophage colony-stimulating factor $(20 \mathrm{ng} / \mathrm{ml})$ containing RPMI-1640 medium, with fresh medium added on days 3 and 6 . After 9 days, non-adherent cells were collected and stimulated with LPS $(1 \mu \mathrm{g} / \mathrm{ml})$ for $48 \mathrm{~h}$ to induce maturation.

Three siRNAs targeting different regions of Jagged 1 mRNA were designed and purchased (RiboBio, Guangzhou, China) together with a scrambled siRNA to serve as a negative control. Harvested BMDCs were transfected with the individual siRNAs using Lipofectamine ${ }^{\circledR} 2000$ Transfection Reagent (Invitrogen, Carlsbad, CA, USA) according to the manufacturer's protocol. Forty-eight hours after transfection, the BMDCs were collected for analysis. We performed RT-PCR to determine their Jagged1 mRNA expression.

We co-cultured siRNA-modified BMDCs in 24-well plates with $\mathrm{T}$ cells stimulated with $\mathrm{rLACK}(100 \mu \mathrm{g} / \mu \mathrm{l})$. The culture supernatants were collected $72 \mathrm{~h}$ later for cytokine analysis and the cells were collected for flow cytometry and qRT-PCR analysis.

\section{Flow Cytometric Analysis}

For cell surface marker analysis, we stained cell samples with fluorochrome-conjugated mAbs (BD Biosciences, San Jose, CA, USA) for $30 \mathrm{~min}$, then washed the samples three times with $2 \%$ FBS in PBS. For intracellular cytokine or transcription factor analysis, cells were stimulated with $50 \mathrm{ng} / \mathrm{ml}$ phorbol myristate acetate plus $500 \mathrm{ng} / \mathrm{ml}$ ionomycin for $4 \mathrm{~h}$ in the presence of $1 \mu \mathrm{g} / \mathrm{ml}$ brefeldin A (BD Biosciences, San Jose, CA, USA), then fixed and permeabilized, followed by cytoplasmic staining with the appropriate fluorochrome-conjugated mAbs (eBioscience, San Diego, CA, USA). We performed sample acquisition with a FACS Aria II (BD Biosciences, Franklin Lakes, NJ, USA) and analyzed the results using FlowJo software.

\section{Analysis of Macrophage and DCs Activation Induced by the LACK $_{156-173}$ Epitope}

\section{Cell Viability Assay}

RAW264.7 cells were purchased from the American Type Culture Collection (Manassas, VA, USA). The effect of rLACK on the viability of RAW264.7 cells was analyzed using the 3-(4,5-dimethylthiazol-2-yl)-2,5-diphenyltetrazolium bromide (MTT) assay. Cells were pre-incubated in 96-well plates for $24 \mathrm{~h}$, then incubated with rLACK $(100 \mu \mathrm{g} / \mu \mathrm{l})$ or LPS $(1 \mu \mathrm{g} / \mathrm{ml})$ for $24 \mathrm{~h}$. After incubation, MTT stock solution $(2 \mathrm{mg} / \mathrm{ml})$ was added to each well, and the cells were incubated for an additional $2 \mathrm{~h}$. 


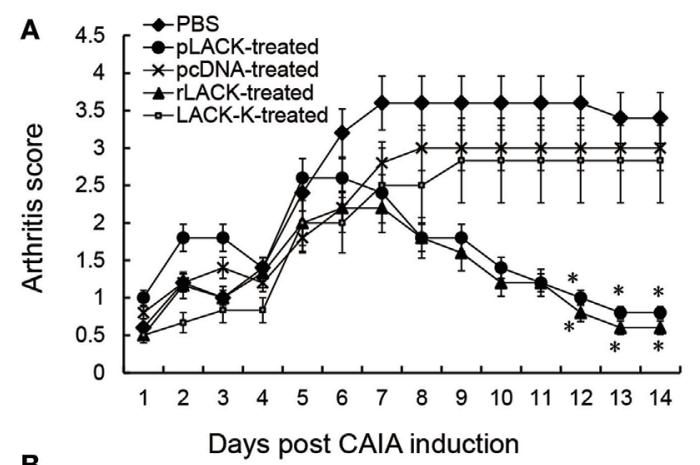

B

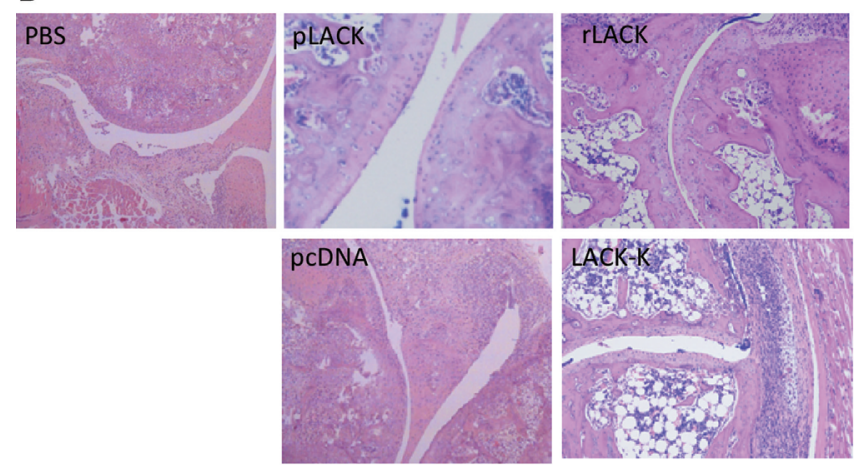

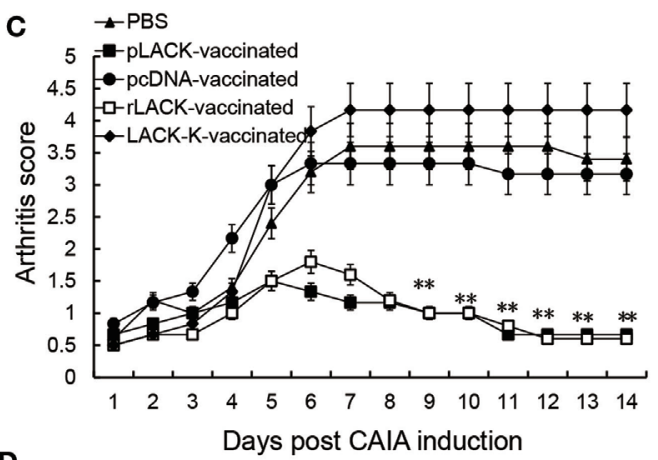

D

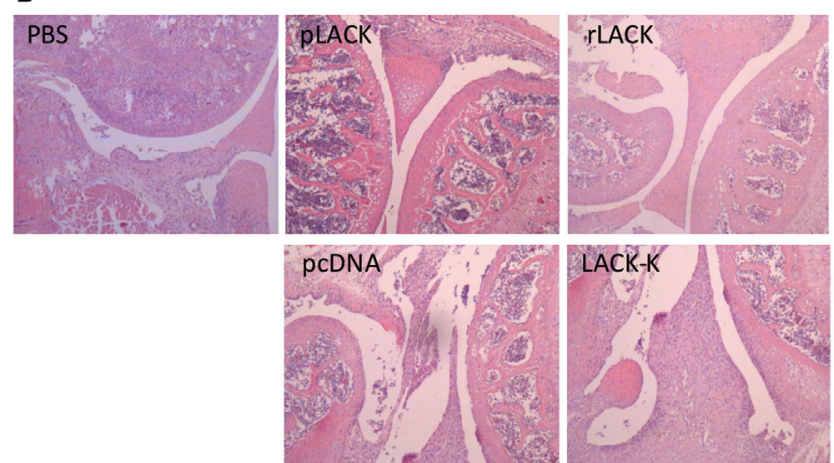

口PBS

DpLACK-treated

口pcDNA-treated

- rLACK-treated

口LACK-K-treated
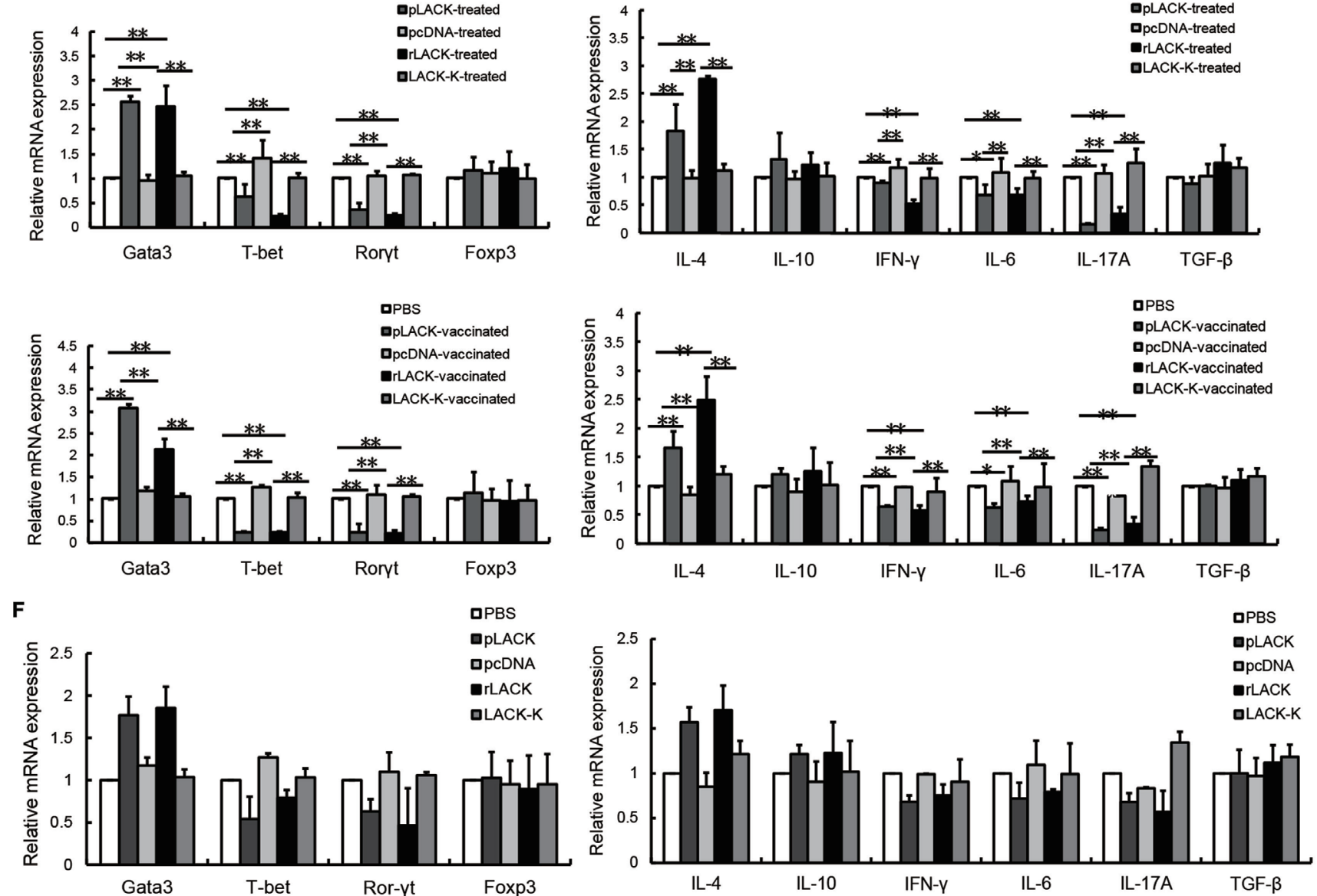

FIGURE 1 | Continued 

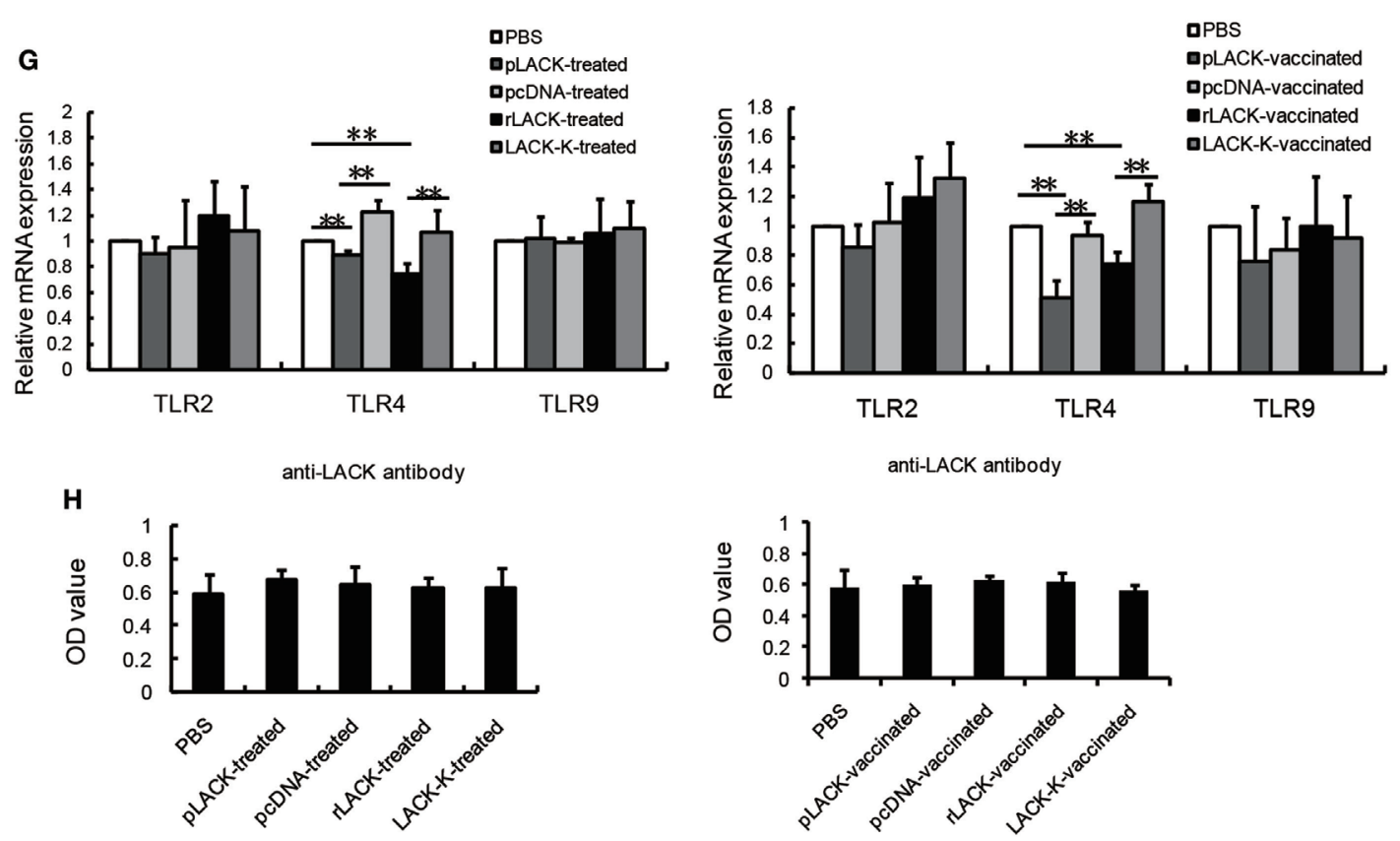

FIGURE 1 | The effect of the LACK ${ }_{156-173}$ epitope in mice with collagen antibody-induced arthritis (CAIA). CAIA mice in the treatment groups were injected with PBS/ pLACK/pcDNA $(100 \mu \mathrm{g})$ or PBS/rLACK/LACK-K $(50 \mu \mathrm{g})$ on day 4. CAIA mice were vaccinated 7 days before monoclonal antibody (mAb) injection. (A-D) The effects of Plack/rLACK treatment (A,B) and vaccination (C,D) on the arthritis scores and histopathology of CAIA mice. Original magnification, 100x. Eight animals in each group. (E) T cell transcription factor and cytokine gene expression in the knee synovium of CAIA mice at day 14. (F) The gene expression levels in normal mice injected with the LACK $156-173$ epitope. Normal mice were injected with PBS/pLACK/pcDNA (100 $\mu$ g) or PBS/rLACK/LACK-K (50 $\mu$ g). 7 days later, T cell transcription factor and cytokine gene expression in the knee joints of mice were determined by quantitative real-time polymerase chain reaction. (G) Toll-like receptors (TLRs) gene expression in the knee synovium of CAIA mice at day 14. (H) Anti-LACK 156-173 $_{3}$ epitope antibodies in the sera of CAIA mice were determined by enzyme-linked immunosorbent assay at day 14. The data are expressed as the mean \pm SEM for five animals in each group, combined from at least three independent experiments. ${ }^{*} p<0.05,{ }^{* *} p<0.01$.

After incubation, the medium was removed and isopropyl alcohol was added to solubilize the formazan salt. The amount of formazan salt was determined by measuring the absorbance at $595 \mathrm{~nm}$ using an ELISA microplate reader (Model 550, Bio-Rad, Hercules, CA, USA).

\section{Targeting Pattern Recognition Receptors (PRRs)}

To investigate the role of PRRs in the macrophage activation induced by rLACK, RAW264.7 macrophages in 12-well plates were pre-incubated with medium containing the toll-like receptor (TLR) 2-specific mAb T2.5; the TLR4-specific mAb MTS510; the mannose receptor (MR)-specific mAb MR5D3; the dectin1-specific mAb AF1756; the dectin-2-specific mAb D2.11E4; the major histocompatibility complex (MHC) class II-specific mAb MAB0874 $(10 \mu \mathrm{g} / \mathrm{ml})$; the mixed inhibitor of the NOD-like receptor (NLR) NOD-IN-1 (25 $\mu \mathrm{M})$, which has balanced inhibitory activity on NOD1 and NOD2; or the NOD1 inhibitor nodinitib-1 $(5 \mu \mathrm{M})$ (MCE, Monmouth Junction, NJ, USA) for $1 \mathrm{~h}$. Next, the cells were treated with $\operatorname{rLACK}(100 \mu \mathrm{g} / \mu \mathrm{l})$ or LPS $(1 \mu \mathrm{g} / \mathrm{ml})$ for $24 \mathrm{~h}$. Then, we measured nitric oxide (NO) production, reactive oxygen species (ROS) generation, and cytokine production in the culture system.

To test the effects of rLACK on DCs deficient for PRRs directly, BMDCs obtained from BALB/c mice in 12-well plates were pre-incubated with medium containing the mAbs against PRRs for $1 \mathrm{~h}$. Next, the cells were treated with $\operatorname{rLACK}(100 \mu \mathrm{g} / \mu \mathrm{l})$ for $24 \mathrm{~h}$. The mRNA expression of cytokines and surface molecules of BMDCs were measured by qRT-PCR.

To investigate if targeting PRRs influenced the effects of the LACK $_{156-173}$ epitope in CAIA mice, we injected $100 \mu \mathrm{g}$ of mAbs against PRRs i.p. on day 4. The mice were scored daily until day 14 . The gene expression levels of inflammatory mediators in the knee joint were measured by qRT-PCR.

\section{NO Assay}

We assayed the supernatants from the RAW264.7 cell cultures for NO production. Each supernatant was mixed with an equal volume of Griess reagent (Sigma-Aldrich, St. Louis, MO, USA), then the light absorbance of the mixture at $540 \mathrm{~nm}$ was determined using a Multiskan ${ }^{\mathrm{TM}}$ Spectrum Microplate reader. The nitrite concentration was determined using a standard curve generated from dilutions of a standard nitrite solution.

\section{Measurement of ROS Generation}

We assessed the changes in fluorescence resulting from the oxidation of the fluorescent probe H2DCFDA (Invitrogen, Carlsbad, CA, USA) to evaluate the levels of intracellular ROS. RAW264.7 cells were incubated with $10 \mu \mathrm{M} \mathrm{H} 2 \mathrm{DCFDA}$ for $1 \mathrm{~h}$ at $37^{\circ} \mathrm{C}$. The 

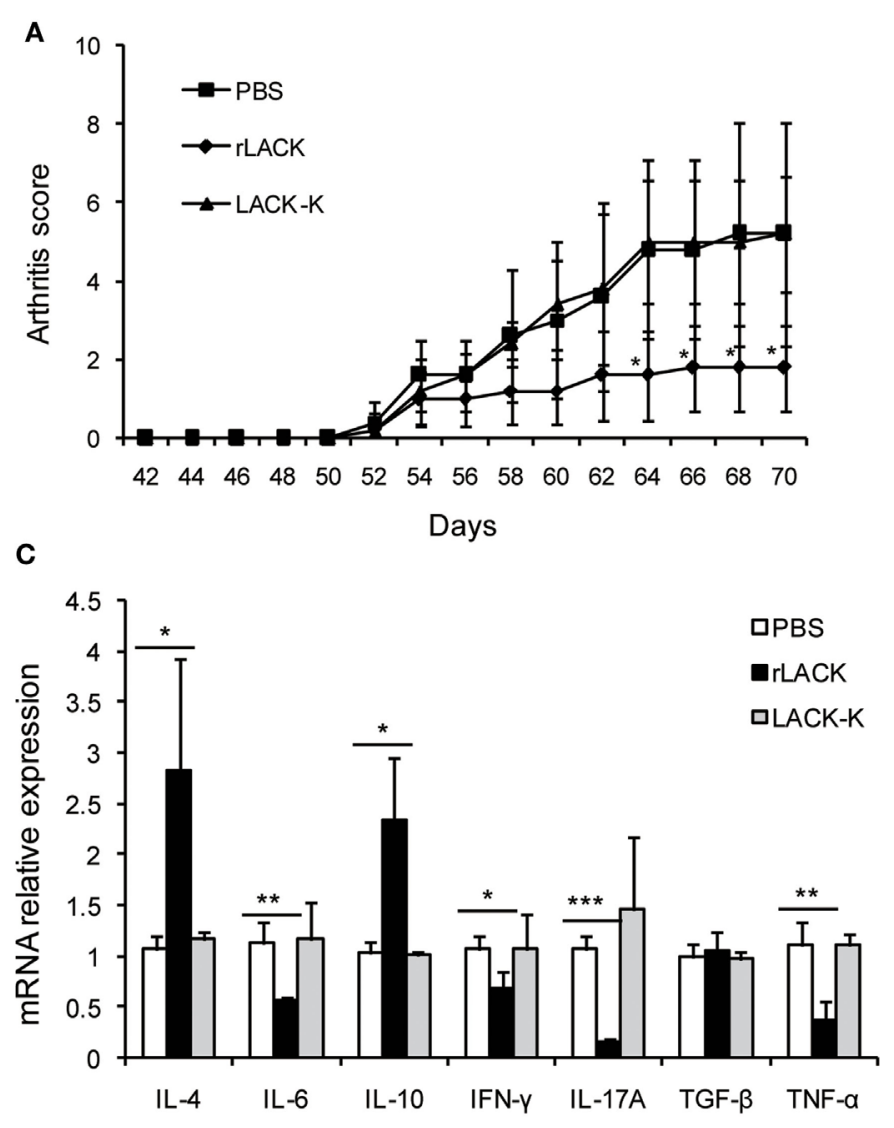

B
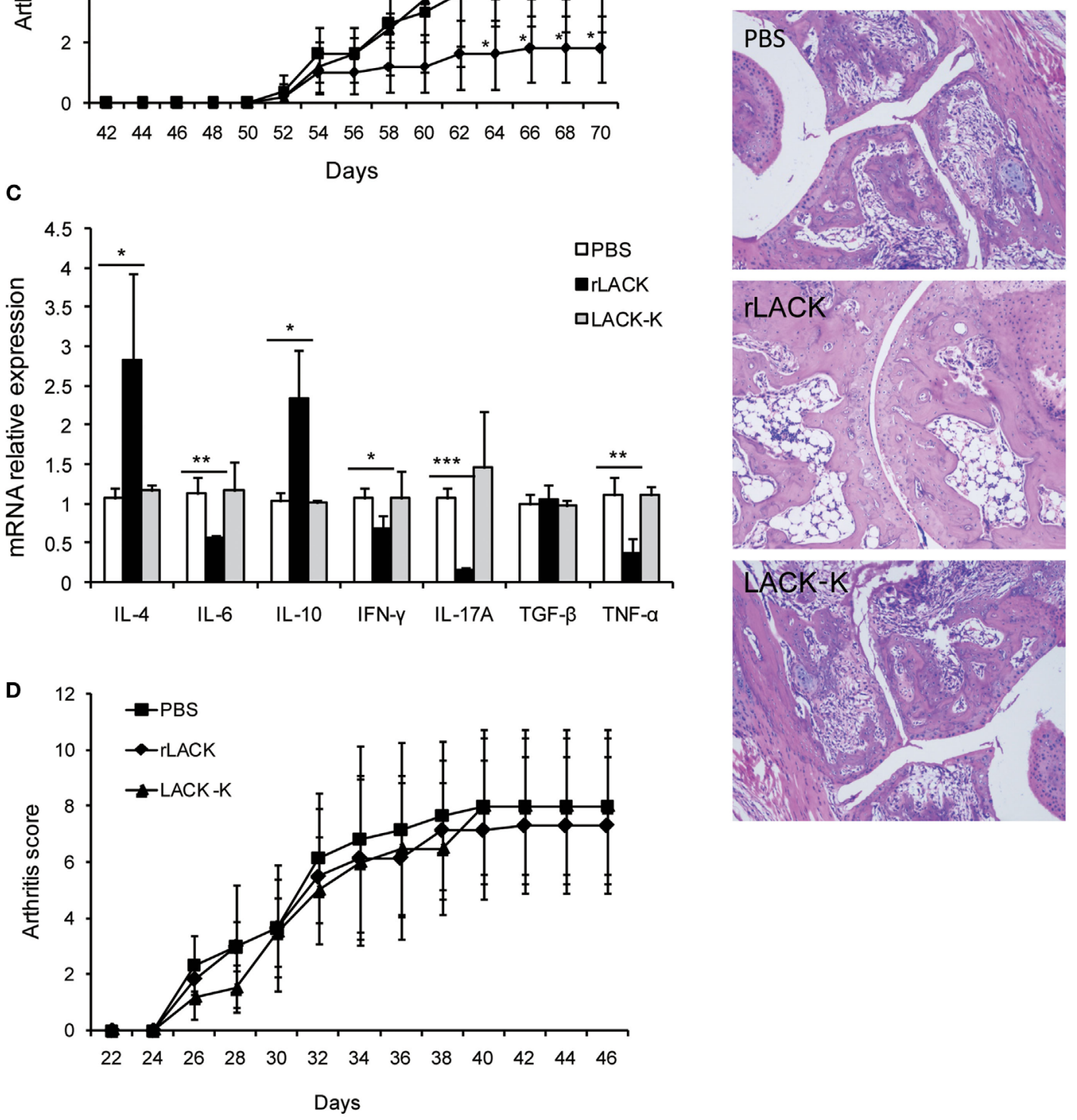

FIGURE 2 | The effect of the $L_{A C K}{ }_{156-173}$ epitope in other animal models of autoimmune arthritis. Proteoglycan (PG)-induced arthritis (PGIA) mice were treated with PBS/rLACK/LACK-K $(50 \mu g)$ after the third injection of PG with 7-day interval. Collagen-induced arthritis (CIA) mice were treated with PBS/rLACK/LACK-K (50 $\mu \mathrm{g})$ after the booster injection with 7-day interval. (A,B) The severity of arthritis was evaluated by arthritis scoring (A) and joint histopathology (B) in PGIA mice. Original

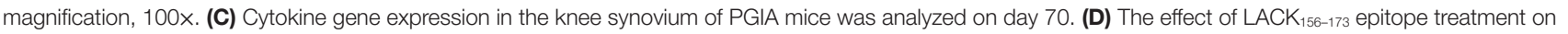
the arthritis scores of CIA mice. The data are expressed as the mean \pm SEM for eight animals in each group, combined from at least three independent experiments. ${ }^{\star} p<0.05,{ }^{\star \star} p<0.01,{ }^{\star \star \star} p<0.001$.

degree of fluorescence was detected (485 nm, excitation; $535 \mathrm{~nm}$, emission) using a microplate spectrofluorometer. For analysis of intracellular ROS production, images of the stained cells were captured using a fluorescence microscope (ECLIPSE 50, Nikon, Tokyo, Japan).

\section{Cytokine Production}

The cytokine levels in the culture supernatants were evaluated with a Mouse Th17 Magnetic Bead Panel Kit (Merck Millipore, Burlington, MA, USA) according to the manufacturer's instructions. 
Yang et al.

Microorganism Epitope Attenuates Autoimmune Arthritis

A
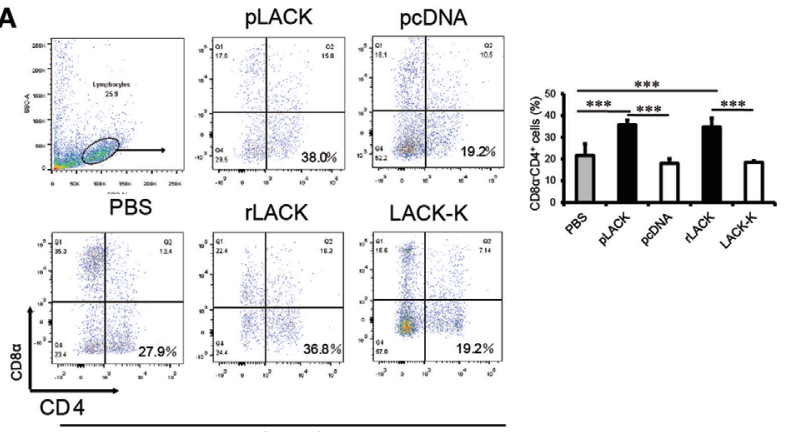

vaccinated

B

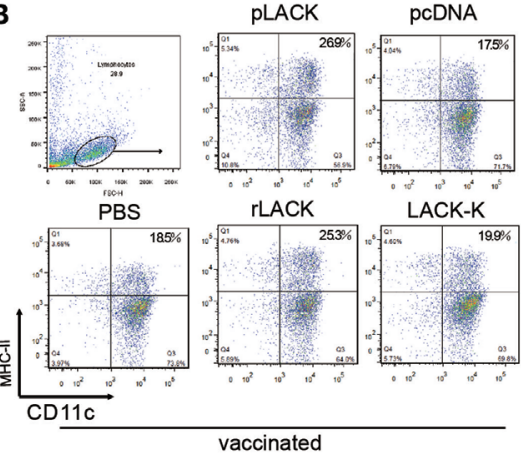

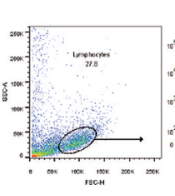
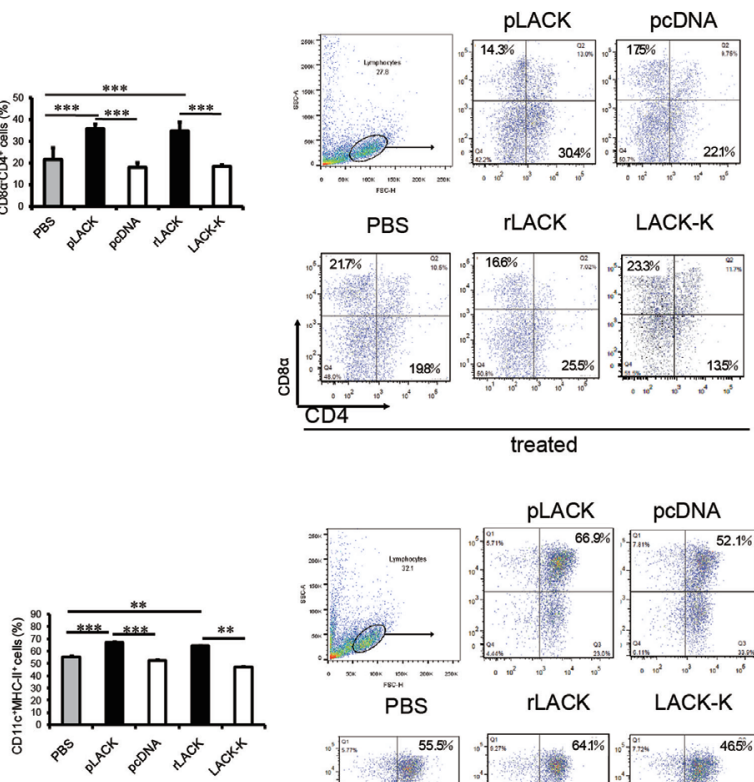

C
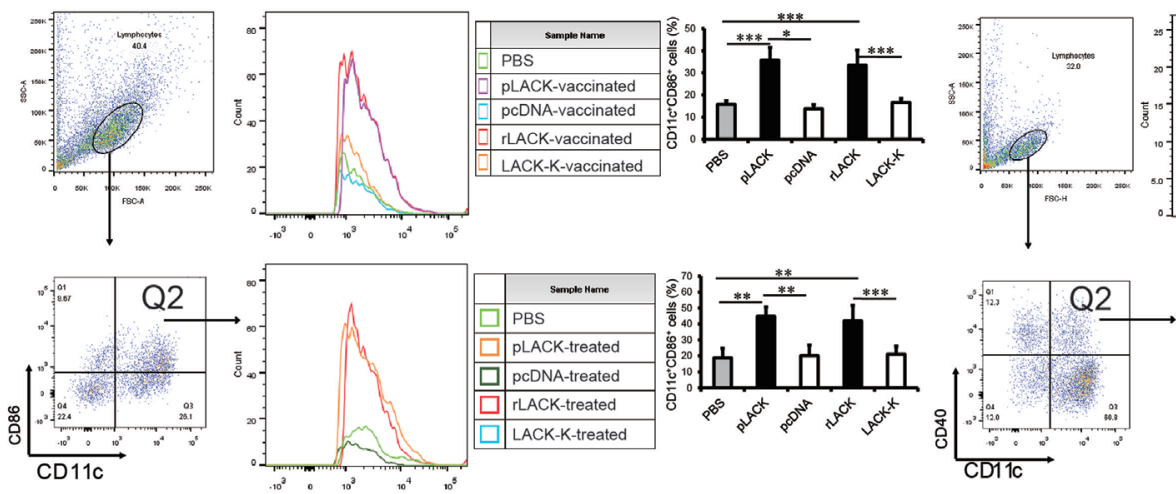

PLACK PcDNA
PBS

FLACK

LACK-K

treated
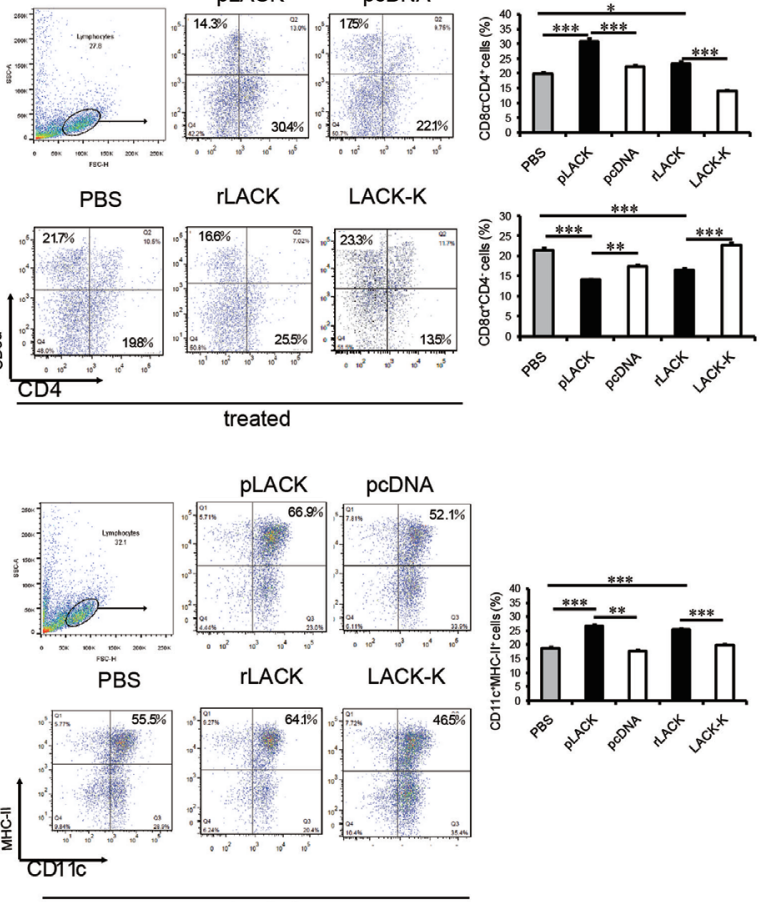

treated

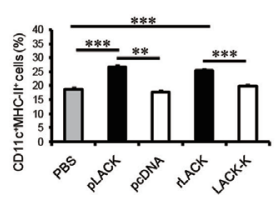

D

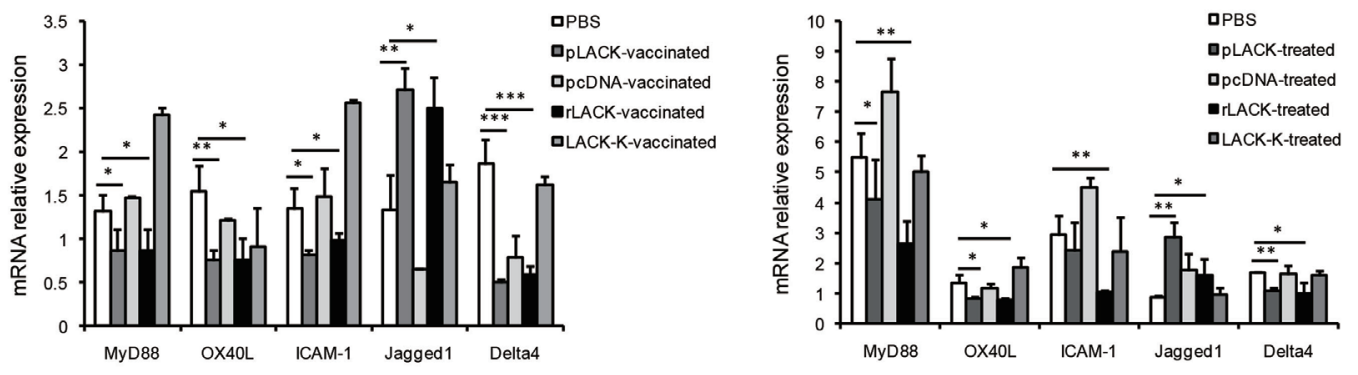

FIGURE 3 | The effects of LACK ${ }_{156-173}$ on the subsets of CD 11 $\mathrm{C}^{+}$dendritic cells (PCs), and their maturity and signaling pathways, in collagen antibody-induced arthritis (CAIA) mice. Single-lymphocyte suspensions from the spleens of CAIA mice were generated by mechanical disruption and red blood cell lysis 7 days after monoclonal antibody $(\mathrm{mAb})$ injection. CD 11 $\mathrm{c}^{+} \mathrm{DCs}$ were purified from splenocytes by magnetic cell sorting. (A) The levels of the surface molecules CD 8 $\alpha$ and CD 4 on splenic DC from LACK ${ }_{156-173}$ epitope-vaccinated or -treated CAIA mice 7 days after injection of the mAb were quantified by flow cytometry. (B) The levels of the surface molecules CD 11c and MHC class II on splenic DC from LACK ${ }_{156-173}$ epitope-vaccinated or -treated CAIA mice 7 days after injection of the mAb were quantified by flow cytometry. (C) The levels of the surface molecules CD11C, CD86, and CD40 on splenic PCs from LACK $156-173$ epitope-vaccinated or -treated CAIA mice 7 days after injection of the mAb were quantified on FACS by double staining. (D) Co-stimulatory molecule, adhesion molecule, toll-like receptor (TLR)4 signaling pathway molecule, and Notch ligand gene expression in PCs from CAIA mice 7 days after the injection of the mAb. One representative of three independent experiments is shown. The results are expressed as the mean \pm SEM. ${ }^{*} p<0.05,{ }^{* *} p<0.01,{ }^{* \star *} p<0.001$.

Frontiers in Immunology | www.frontiersin.org

7

July 2018 | Volume 9 | Article 1528 


\section{Statistical Analysis}

We used GraphPad Prism software (version 5.01) for the statistical analyses. We applied the Mann-Whitney $U$ test or Student's $t$-test for two-group comparisons. The data are displayed as the mean \pm SEM. A $p$-value $<0.05$ was considered statistically significant.

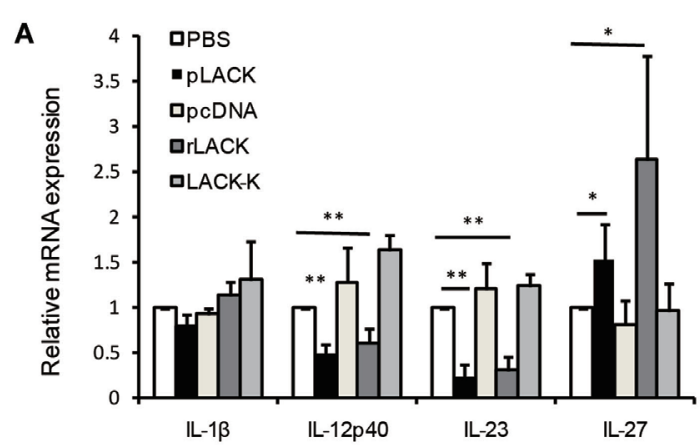

B
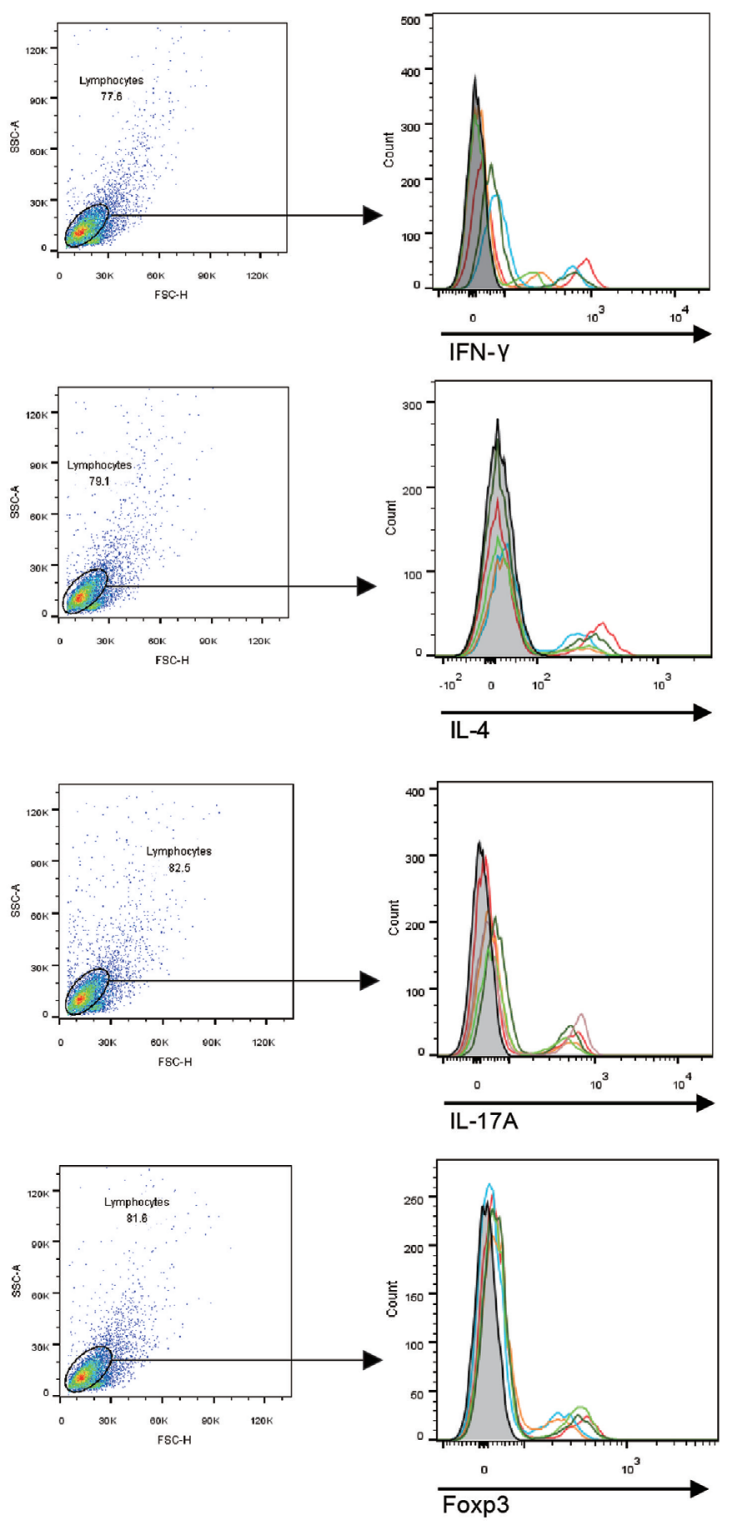
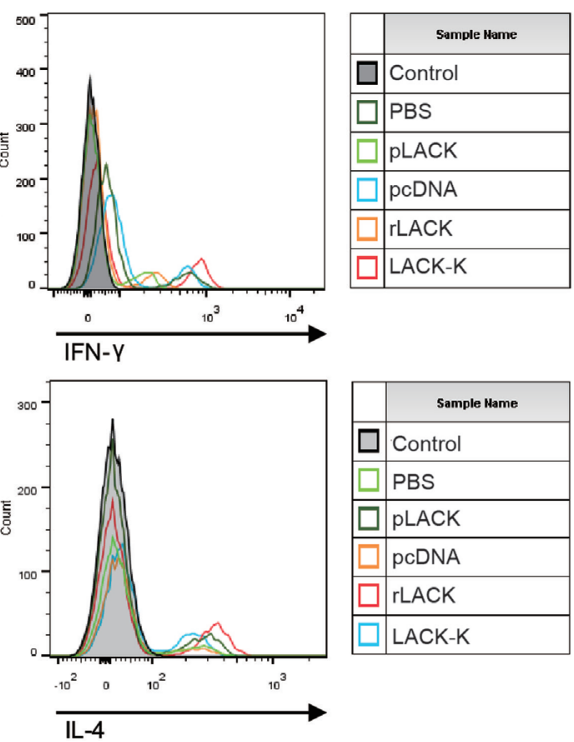

$\square$ LACK-K
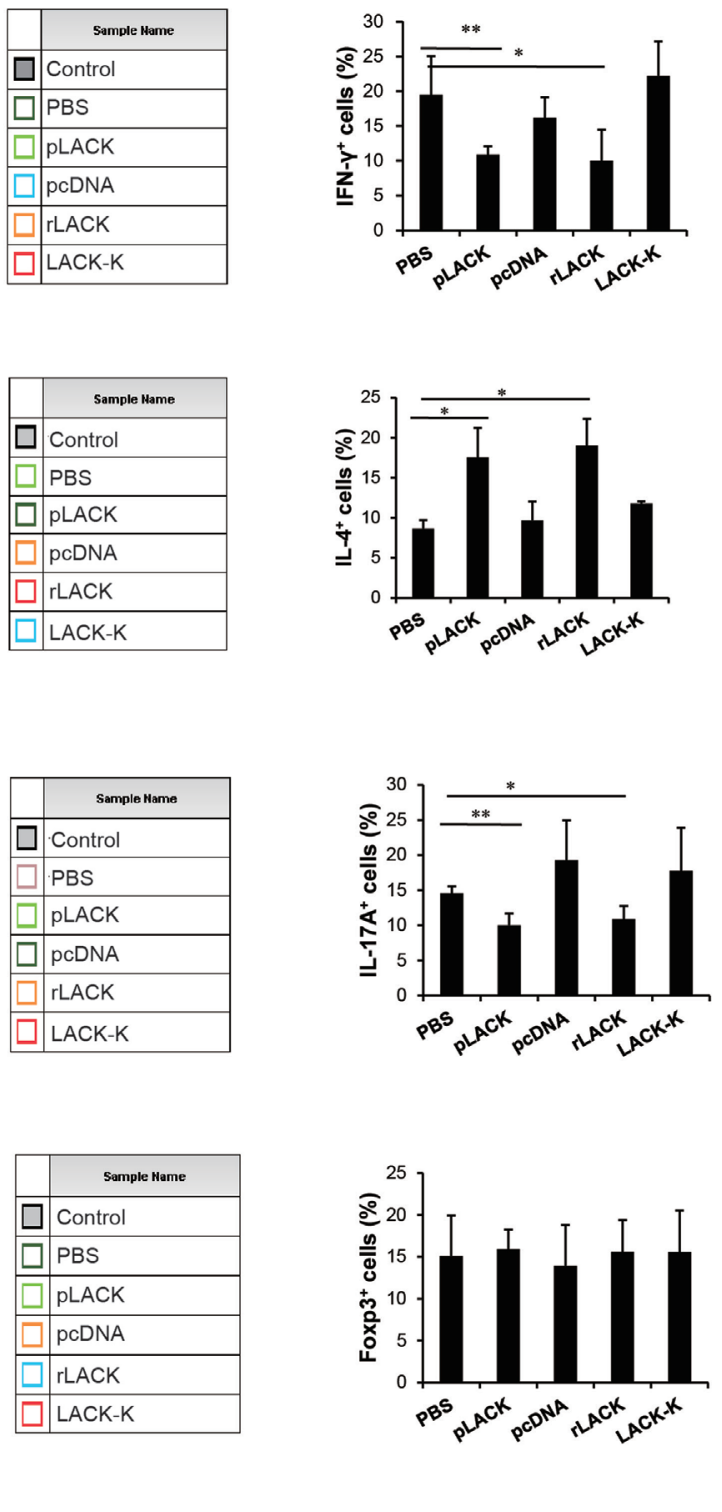

FIGURE 4 | Continued 
C

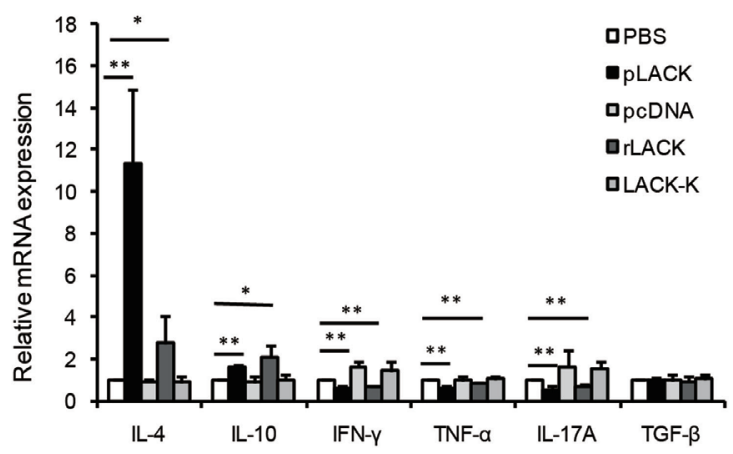

D

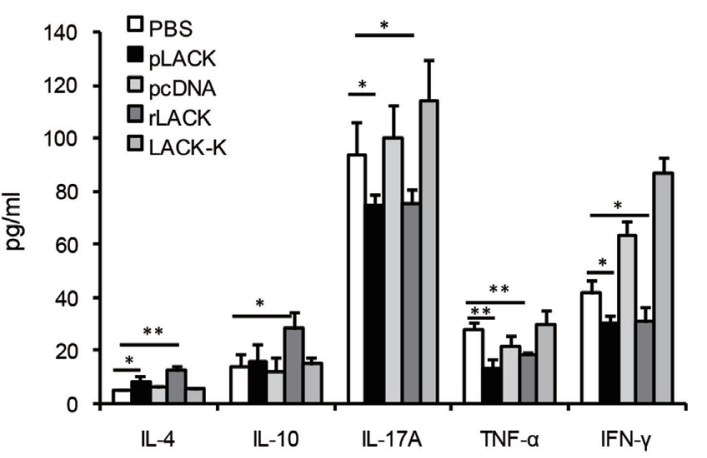

FIGURE 4 | The effect of LACK $156-173$ epitope-matured dendritic cells (DCs) in collagen antibody-induced arthritis (CAIA) mice on T cell polarization and function in vitro. LACK ${ }_{156-173}$ epitope-matured CD11 $\mathrm{C}^{+} \mathrm{DC}$ were prepared from the spleens of CAIA mice, as described in Section "Analysis of the Phenotypes of DCs and the In Vitro Polarization of T Cells From CAIA Mice." CD11 $\mathrm{C}^{+} \mathrm{DC}$ s were co-cultured for $72 \mathrm{~h}$ with T cells, isolated via nylon wool fiber in a syringe, from the spleens of BALB/c mice that had been i.p. injected with $100 \mu \mathrm{g} \mathrm{OVA}_{323-339} 7$ days before isolation. (A,C) Cytokine mRNA expression. (B) The numbers of interleukin (IL)-4+ cells, IFN- $\gamma^{+}$cells, IL-17A cells, and Foxp3 $3^{+}$cells were measured by flow cytometry. (D) The concentrations of the cytokines in the culture supernatants. One representative of three independent experiments is shown. Results are expressed as mean \pm SEM. ${ }^{*} p<0.05,{ }^{* *} p<0.01$.

\section{RESULTS}

\section{LACK $_{156-173}$ Epitope Attenuates Arthritis Severity and Regulates Effector T Cell Responses}

The altered LACK-K peptide does not induce IL-4 production by $\mathrm{V} \beta 4^{+} / \mathrm{V} \alpha 8^{+} \mathrm{CD} 4^{+} \mathrm{T}$ cells in BALB/c mice. The difference resulting from the single amino acid substitution suggests limited diversity in the endogenous $\mathrm{T}$ cell repertoire that recognizes LACK (16). Therefore, we used LACK-K as a negative control for rLACK in our research. To investigate the anti-inflammatory and immunomodulatory effects of the $\mathrm{LACK}_{156-173}$ epitope in arthritis, we synthesized rLACK (the synthetic polypeptide of the LACK $_{156-173}$ epitope) and pLACK (the recombinant LACK LF-173 $_{15-1}$ epitope expression plasmid), and evaluated their effect on the development of CAIA, an animal model of RA. The clinical scores of the pLACK- and rLACK-treated or -vaccinated groups were significantly lower than those of the control arthritis groups (Figures 1A,C). Histological examination of the knees confirmed that the $\mathrm{LACK}_{156-173}$ epitope ameliorated arthritis, with regard to synovitis and the erosion of the cartilage and bone (Figures 1B,D).

To determine if the epitope affected cytokine production and $\mathrm{T}$ cell proliferation, we examined the gene expression levels of inflammatory mediators in the knee synovium. The gene expression levels of IL- 4 and the Th2 cell transcription factor Gata3 were significantly higher in the pLACK- and rLACK-treated or -vaccinated groups than in the control arthritis group. Moreover, the gene expression levels of the pro-inflammatory cytokines IFN- $\gamma$, IL-6, and IL-17A, and the Th1 and Th17 cell transcription factors T-bet and Ror $\gamma$ t, were lower in the pLACK- or rLACK-injected mice (Figure 1E). We also examined the gene expression levels of the cytokines and effector $\mathrm{T}$ cell transcription factors in normal mice treated with pLACK or rLACK, which led to similar, but weaker, results
(Figure 1F). These data indicate that both vaccination and treatment with the $\mathrm{LACK}_{156-173}$ epitope inhibit joint inflammation and modulate effector $\mathrm{T}$ cell response, by inducing Th2 cell responses and downregulating Th1 and Th17 cell responses in CAIA mice.

Toll-like receptors recognize microbial products and are involved in the regulation of $\mathrm{T}$ cell activation $(21,22)$, so we examined the gene expression levels of TLR2, 4, and 9 in the knee synovium. The TLR4 gene expression levels were significantly lower in the pLACK- and rLACK-treated or -vaccinated groups than in the controls (Figure 1G). These results show that the LACK $_{156-173}$ epitope decreased the expression of TLR4 in CAIA mice, which may influence $\mathrm{T}$ cell activation.

The levels of anti-LACK ${ }_{156-173}$ epitope antibodies in the serum were not statistically different among the groups (Figure $\mathbf{1 H}$ ), suggesting that pLACK and rLACK injection did not induce the production of antigen-specific antibodies. The effects of pLACK and rLACK in CIA mice were similar in above experiments. So we consider the polypeptide and the recombinant expression plasmid of the $\mathrm{LACK}_{156-173}$ epitope have equivalent potential for treatment.

\section{The Effect of the LACK $_{156-173}$ Epitope Is Dependent on MHC Class II Molecule I-A ${ }^{d}$}

The $\mathrm{LACK}_{156-173}$ epitope is presented by MHC class II I-A ${ }^{\mathrm{d}}$ molecules, and recognized by $\mathrm{V} \beta 4^{+} / \mathrm{V} \alpha 8^{+} \mathrm{T}$ cells. To further investigate the therapeutic potential of the $\mathrm{LACK}_{156-173}$ epitope, we administered it to PGIA and CIA mice, which are murine models of autoimmune arthritis. CIA is induced in DBA/1 mice (MHC class II I-A ${ }^{\mathrm{q}}$ ), which have different $\mathrm{MHC}$ molecules with $\mathrm{BALB} / \mathrm{c}$ mice (MHC class II I-A ${ }^{\mathrm{d}}$ ). We found that rLACK peptide treatment led to significantly lower clinical scores and fewer histopathological alterations in PGIA mice than those of the arthritis controls (Figures 2A,B). In the rLACK-treated group, IFN- $\gamma$, TNF- $\alpha$, 
IL-6, and IL-17A were markedly reduced to the levels found in the control mice. Meanwhile, rLACK treatment increased IL-4 and IL-10 levels in the knee synovium (Figure 2C). Thus, treatment with rLACK has therapeutic effects in PGIA mice. However, we did not observe similar results in CIA mice (Figure 2D), perhaps due to the lack of MHC class II I- $\mathrm{A}^{\mathrm{d}}$ molecules in DBA/ 1 mice.
The LACK ${ }_{156-173}$ Epitope Modulates the Differentiation and Maturation of DCs in CAIA Mice, Thereby Influencing T Cell Polarization

As antigen-presenting cells (APCs), such as DCs, are key players during both the initiation and progression of autoimmune

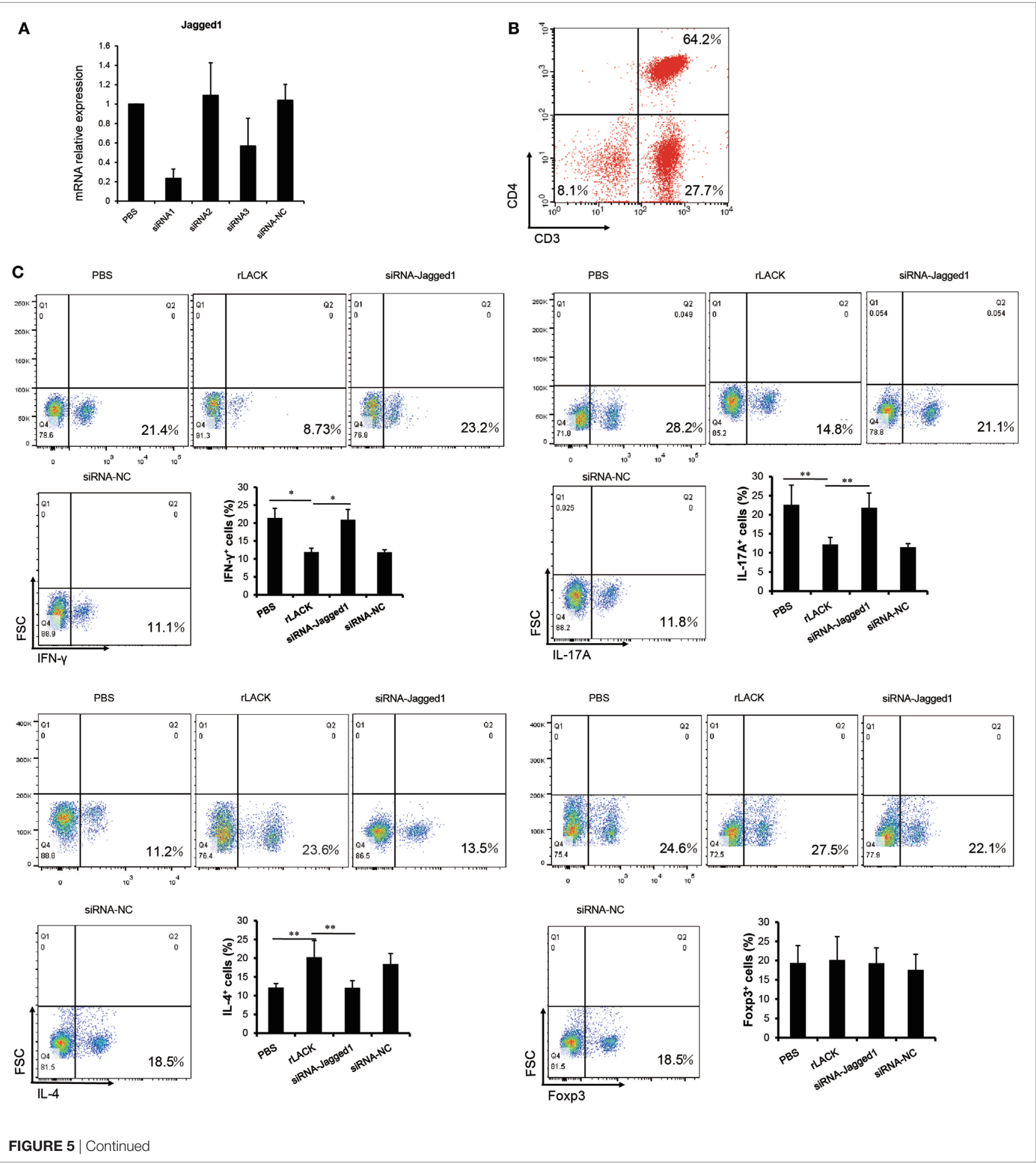


D

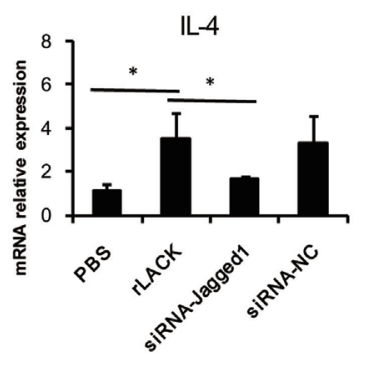

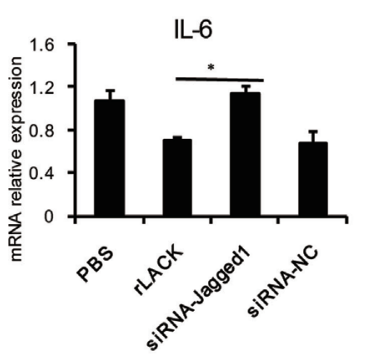
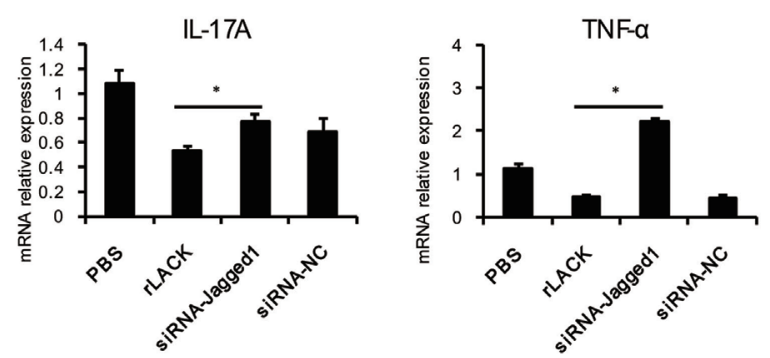

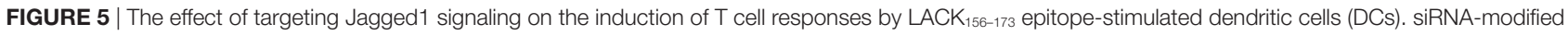
bone marrow-derived dendritic cells (BMDCs) were co-cultured with T cells stimulated by rLACK (100 $\mu \mathrm{g} / \mu \mathrm{l})$. (A) Three siRNAs targeting different regions of Jagged1 mRNA were designed and purchased together with a scrambled siRNA to serve as a negative control. Harvested BMDCs were transfected by using Lipofectamine with three siRNAs targeting different regions of Jagged1 mRNA and a scrambled siRNA to serve as a negative control. $24 \mathrm{~h}$ later, we performed quantitative real-time polymerase chain reaction (qRT-PCR) to determine their Jagged1 mRNA expression in the BMDCs. (B) The purity of CD3+CD4+ cells in isolated $\mathrm{T}^{+}$cells was measured by flow cytometry. (C) The numbers of interleukin (IL)- $4^{+}$cells, IFN- $\gamma^{+}$cells, IL-17A+ cells and Foxp3 ${ }^{+}$cells in the co-culture system were examined using flow cytometry. (D) Cytokine mRNA expression was measured by qRT-PCR analysis. Dot plots are representative of one of three experiments. The results are expressed as the mean \pm SEM, combined from at least three independent experiments. ${ }^{*} p<0.05,{ }^{* *} p<0.01$.

responses, which include effector $\mathrm{T}$ cell responses $(23,24)$. To further explore the modulation of the adaptive immune response by the $\mathrm{LACK}_{156-173}$ epitope, we measured the quantity of CD11c ${ }^{+}$ DCs in the spleen, as well as their surface marker and cellular signaling pathway molecule expression.

We found significantly more $\mathrm{CD} 4{ }^{+} \mathrm{CD} 8 \alpha^{-} \mathrm{CD} 11 c^{+} \mathrm{DCs}$ in the pLACK- and rLACK-vaccinated CAIA mice than in the controls (Figure 3A), indicating that the epitope affected DC subsets $(25,26)$. We found a greater number of DCs expressing the surface molecules MHC class II and CD86 in the pLACK- or rLACK-vaccinated CAIA mice (Figures 3B,C), suggesting that the epitope promoted DC maturation $(27,28)$. The numbers of $\mathrm{CD}^{+} \mathrm{CD} 8 \alpha^{-} \mathrm{CD} 11 \mathrm{c}^{+}$DCs were also significantly higher and the numbers of $\mathrm{CD} 4{ }^{-} \mathrm{CD} 8 \alpha^{+} \mathrm{CD} 11 \mathrm{c}^{+} \mathrm{DCs}$ were lower in the pLACK- and rLACK-treated groups than in the controls. We observed a higher proportion of DCs expressing the surface molecules MHC class II, CD40, and CD86 in the pLACK- and rLACK-treated mice than in the controls (Figures 3A-C). The gene expression levels of the pro-inflammatory co-stimulatory molecule OX40L, the adhesion molecule ICAM-1, and the TLR4 signaling pathway molecule MyD88 were significantly lower in the pLACK- and rLACK-treated and -vaccinated groups. The gene expression of the Notch ligand Delta4, which has been reported to direct the differentiation of Th17 cells $(29,30)$, was significantly lower in the pLACK- and rLACK-treated or -vaccinated groups. On the contrary, gene expression of the Notch1 ligand Jagged1 was significantly higher than in the controls, which confirmed that the epitope drives the differentiation of Th2 cells (Figure 3D). Taken together, these results demonstrate that $\mathrm{CD} 11 \mathrm{c}^{+} \mathrm{DC}$ subsets, maturity, intracellular signaling pathways, and interactions with $\mathrm{T}$ cells are modulated by the LACK $_{156-173}$ epitope.

To further investigate the functions of DCs that are affected by the LACK $_{156-173}$ epitope, we co-cultured DCs from CAIA mice treated with the $\mathrm{LACK}_{156-173}$ epitope with $\mathrm{T}$ cells in vitro. The gene expression levels of the pro-inflammatory cytokines IL-12p40 and IL-23 were significantly lower and the level of the anti-inflammatory cytokine IL-27 was higher in the cultures with the cells from the pLACK- and rLACK-treated groups (Figure 4A), indicating that the $\mathrm{LACK}_{156-173}$ epitope regulates cytokine secretion by DCs. The numbers of IFN $-\gamma^{+}$cells and IL- $17 \mathrm{~A}^{+}$cells were significantly lower, and the number of IL- $4^{+}$ cells was higher, in the cultures with the cells from the pLACKand rLACK-treated groups (Figure 4B). On the other hand, the cultures of the DCs from the $\mathrm{LACK}_{156-173}$ epitope-stimulated groups co-cultured with $\mathrm{T}$ cells had significantly lower IFN- $\gamma$, TNF- $\alpha$, and IL-17A gene expression and secretion, and increased IL-4 and IL-10 production (Figures 4C,D), in comparison with the cultures containing non-epitope-stimulated DCs. These findings further support the idea that the $\mathrm{LACK}_{156-173}$ epitope polarizes DCs toward a Th2-promoting profile.

\section{The LACK $_{156-173}$ Epitope Polarizes DCs and Induces Th2 Responses via Jagged1 Signaling}

Targeting Notch1 signaling on DCs has been proposed as a novel strategy for modulating Th2 immune responses (31). So, we evaluated if Notch1 signaling was necessary for the $\mathrm{LACK}_{156-173}$ epitope to polarize DCs, by using siRNA to silence Jagged1 expression in BMDCs, which were cultured from bone marrow cells of BALB/c mice. Forty-eight hours after transfection, we selected one of three siRNAs based on the levels of Jagged1 gene expression in the transfected cells (Figure 5A), then we co-cultured the siRNA-modified BMDCs with $\mathrm{T}$ cells. Also, we examined the purity of $\mathrm{CD}^{+} \mathrm{CD}^{+}$cells in isolated $\mathrm{T}$ cells (Figure 5B). In the co-colure system, we found that the Jagged 1 siRNA significantly reduced the number of IL $-4^{+}$cells induced by rLACK, whereas it increased the number of IFN- $\gamma^{+}$cells and IL-17 $\mathrm{A}^{+}$cells (Figure 5C). IL-4 production was also decreased, and IL-6, TNF- $\alpha$, and IL-17A were upregulated by Jagged 1 siRNA transfection (Figure 5D). Thus, the $\mathrm{LACK}_{156-173}$ epitope polarizes DCs to induce Th2 responses, mainly via Jagged1 signaling. 


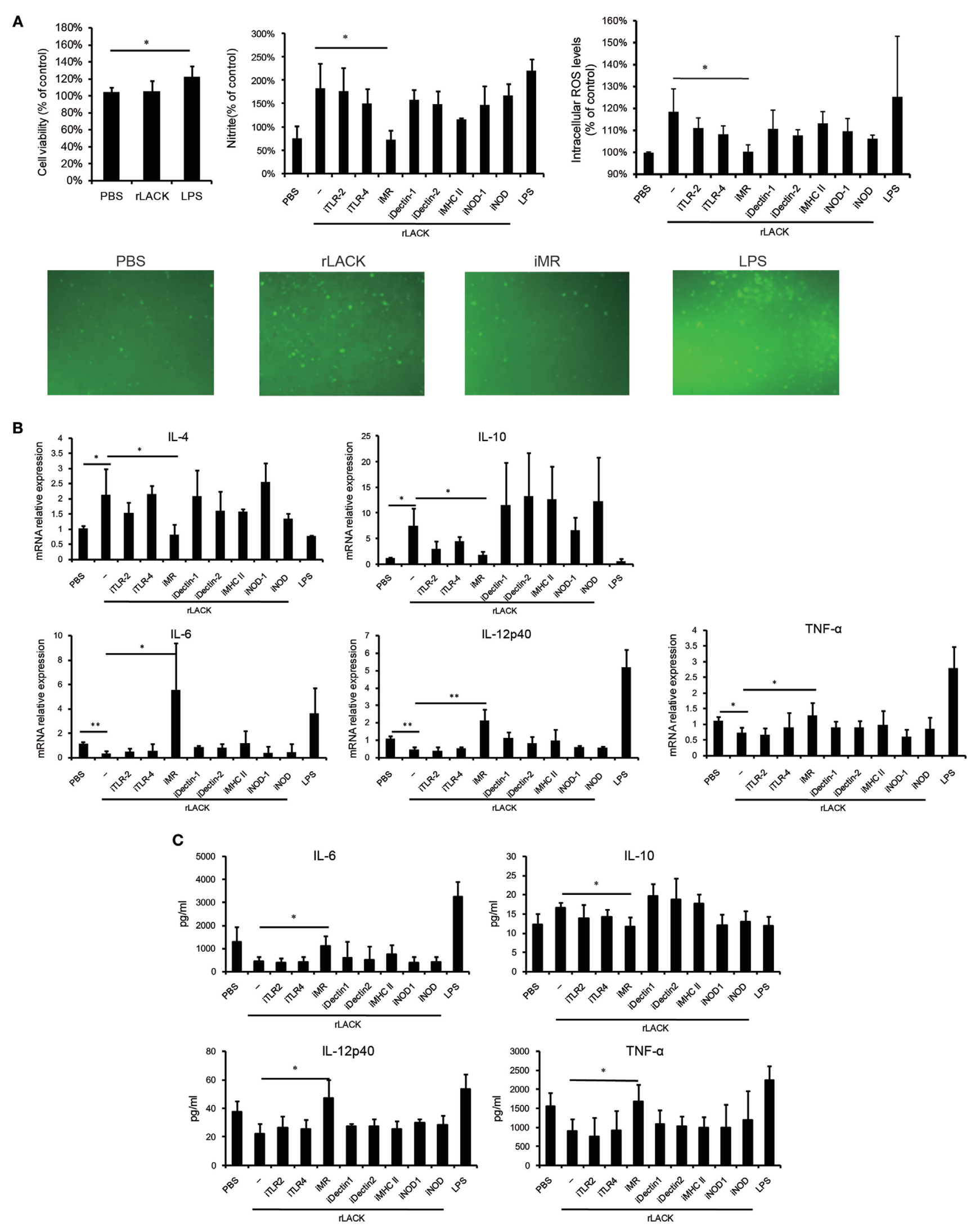

FIGURE 6 | Continued 
FIGURE 6 | The effect of anti-mannose receptor (MR) on macrophage and dendritic cells (DCs) activation induced by the LACK ${ }_{156-173}$ epitope. RAW264.7 macrophages were pre-incubated with medium containing monoclonal antibodies (mAbs) against toll-like receptor (TLR)2, TLR4, MR, dectin-1, dectin-2, or MHC class II $(10 \mu \mathrm{g} / \mathrm{ml})$, or NOD-IN-1 $(25 \mu \mathrm{M})$ or nodinitib-1 $(5 \mu \mathrm{M})$ for $1 \mathrm{~h}$. Then, the cells were treated with rLACK $(100 \mu \mathrm{g} / \mu \mathrm{l})$ or lipopolysaccharide $(\mathrm{LPS})(1 \mu \mathrm{g} / \mathrm{ml})$ for $24 \mathrm{~h}$. (A) The effect of rLACK on cell viability was analyzed using an MTT assay. The supernatants of the RAW264.7 cell cultures were examined for NO production using Griess reagent. The degree of intracellular reactive oxygen species (ROS) generation was detected using a microplate spectrofluorometer. Images of the stained cells were captured by immunofluorescence microscopy. (B) Cytokine mRNA expression was measured by quantitative real-time polymerase chain reaction (qRT-PCR) analysis. (C) The concentrations of the cytokines in the culture supernatants. Data are expressed as the mean \pm SEM combined from at least three independent experiments. ${ }^{*} p<0.05,{ }^{* *} p<0.01$.

\section{Anti-MR Inhibits Macrophage Activation and the Functions of DCs Induced by the LACK $_{156-173}$ Epitope}

Innate immunity responds immediately to infection and damage; it is activated through the binding of conserved pathogen- or damage-associated molecules to PRRs on DCs and other innate immune cell types, and it directs the adaptive immune response (32). Most PRRs are expressed on both DCs and macrophages. Thus, we used RAW264.7 macrophages to investigate if the $\mathrm{LACK}_{156-173}$ epitope activates DCs through PRRs. We found that the rLACK peptide did not affect cell viability (Figure 6A). To investigate if rLACK could induce macrophage activation, we incubated RAW264.7 cells with rLACK or LPS for $24 \mathrm{~h}$. We observed significantly higher NO and ROS generation in the cells treated with rLACK or LPS than in the controls (Figure 6A). IL-4 and IL-10 production were also increased, and IL-6, TNF- $\alpha$, and IL-12p40 were downregulated, compared to their expression in the PBS control, by rLACK treatment (Figures 6B,C). These effects were abolished by using an anti-MR mAb, but not by targeting many other PRRs (Figures 6A-C). These data suggest that rLACK may bind MR to induce macrophage activation.

To further verify if rLACK activates DCs and modulates the functions of DCs through MR, we used BMDCs obtained from $\mathrm{BALB} / \mathrm{c}$ mice, which were pre-incubated with $\mathrm{mAb}$ against MR for $1 \mathrm{~h}$. The mAb against Dectin- 1 was served as a control $\mathrm{mAb}$. Then, the cells were treated with $\mathrm{rLACK}(100 \mu \mathrm{g} / \mu \mathrm{l})$ for $24 \mathrm{~h}$. We found the effect of upregulating MHC II and Jagged 1 mRNA expression of BMDCs were abolished by anti-MR $\mathrm{mAb}$, which indicated that $\mathrm{LACK}_{156-173}$ epitope induces DCs activation and Jagged 1 signaling by binding MR. The effect of upregulating IL-27 mRNA expression of BMDCs, and downregulating IL-12p40, IL-23 mRNA expression by rLACK were also abolished by anti-MR mAb (Figure 7A), which indicated that $\mathrm{LACK}_{156-173}$ epitope modulates cytokines secretion of DCs by binding MR. Taken together, these results demonstrate that DC maturity and the modulatory effect on $\mathrm{T}$ cells of DCs are induced by the $\mathrm{LACK}_{156-173}$ epitope through MR. In addition, the therapeutic effect of rLACK in CAIA mice was blocked by anti-MR mAb injection (Figure 7B). The effect of upregulating IL-4 mRNA expression and downregulating IL-17, IFN- $\gamma$ mRNA expression in knee joint by rLACK was also blocked by anti-MR mAb injection (Figure 7C). Therefore, we consider that the $\mathrm{LACK}_{156-173}$ epitope polarizes DCs, modulates effector $\mathrm{T}$ cell response, and induces remission of arthritis by binding MR.

\section{DISCUSSION}

Infectious microorganisms can exert immunoregulatory and immunosuppressive functions (33). Ova, extracts, and macromolecular substances are the most frequently used microorganismderived immune-modulatory agents (34-36); they may induce infection or activate existing immunity. In this research, we first explored a single epitope of microorganism therapy with $\mathrm{LACK}_{156-173}$. We found that the epitope did not elicit inflammation and markedly ameliorated murine autoimmune arthritis. The therapeutic effects appeared to be mediated by the regulation of the differentiation, maturation, and function of DCs via MR, resulting in the upregulation of Jagged 1 and leading to Th2 polarization.

The single epitope $\mathrm{LACK}_{156-173}$ could drive naive T cells into a Th2 response in BALB/c mice. In our research, it does not only induce Th2 inflammatory response but also inhibit the Th1 and Th17 pathways, and blocked the production of pro-inflammatory cytokines. Due to the pathologic role of pro-inflammatory cytokines, such as TNF- $\alpha$, in RA, cytokine inhibitors have been developed for the treatment of RA. However, these biological drugs are effective in a limited number of patients. Our research demonstrated that the $\mathrm{LACK}_{156-173}$ epitope, which has broad regulatory effects on the balance of T cell subsets, may induce a better response in a wider variety of RA patients. H164, a positively charged amino acid within the LACK $_{156-173}$ epitope (ICFSPSLEHPIVVSGSWD), determines its binding affinity for MHC class II molecules and the negatively charged motif in the T cell receptor (TCR) $\beta$ chain (16). Therefore, LACK-K164 did not elicit responses in BALB/c mice. Consequently, $\mathrm{H} 164$ in the $\mathrm{LACK}_{156-173}$ epitope seems to be very important for the therapeutic effect of the epitope.

Dendritic cells, the most powerful APCs, carry antigens to the draining lymph nodes, where they promote the activation, differentiation, and polarization of naive $\mathrm{T}$ cells into effector $\mathrm{T}$ cell subsets. Conventional DCs (cDCs) are professional APCs that specialize in these functions. After contact with antigens, DCs undergo a process of maturation, then migrate to the $\mathrm{T}$ cell areas of lymph nodes. The maturation process includes the increased expression of MHC and co-stimulatory molecules, such as CD40, CD80, CD86, and CD54; decreased antigen capture and phagocytic capacity; enhanced cytokine secretion; and different patterns of chemokine receptor expression and chemokine production, enabling DC migration and the recruitment of other cell types $(37,38)$. CD $8 \alpha^{-}$cDCs are the most efficient at Th2 cell polarization, whereas $\mathrm{CD} 8 \alpha^{+}$cDCs are particularly efficient at Th1 cell activation $(19,39,40)$. Our data showed that LACK $_{156-173}$ epitope injection resulted in the expansion of $\mathrm{CD} 4^{+} \mathrm{CD} 8 \alpha^{-} \mathrm{CD} 11 \mathrm{c}^{+}$ DCs; a reduction in $\mathrm{CD} 4^{-} \mathrm{CD} 8 \alpha^{+} \mathrm{CD} 11 \mathrm{c}^{+} \mathrm{DCs}$; increased 

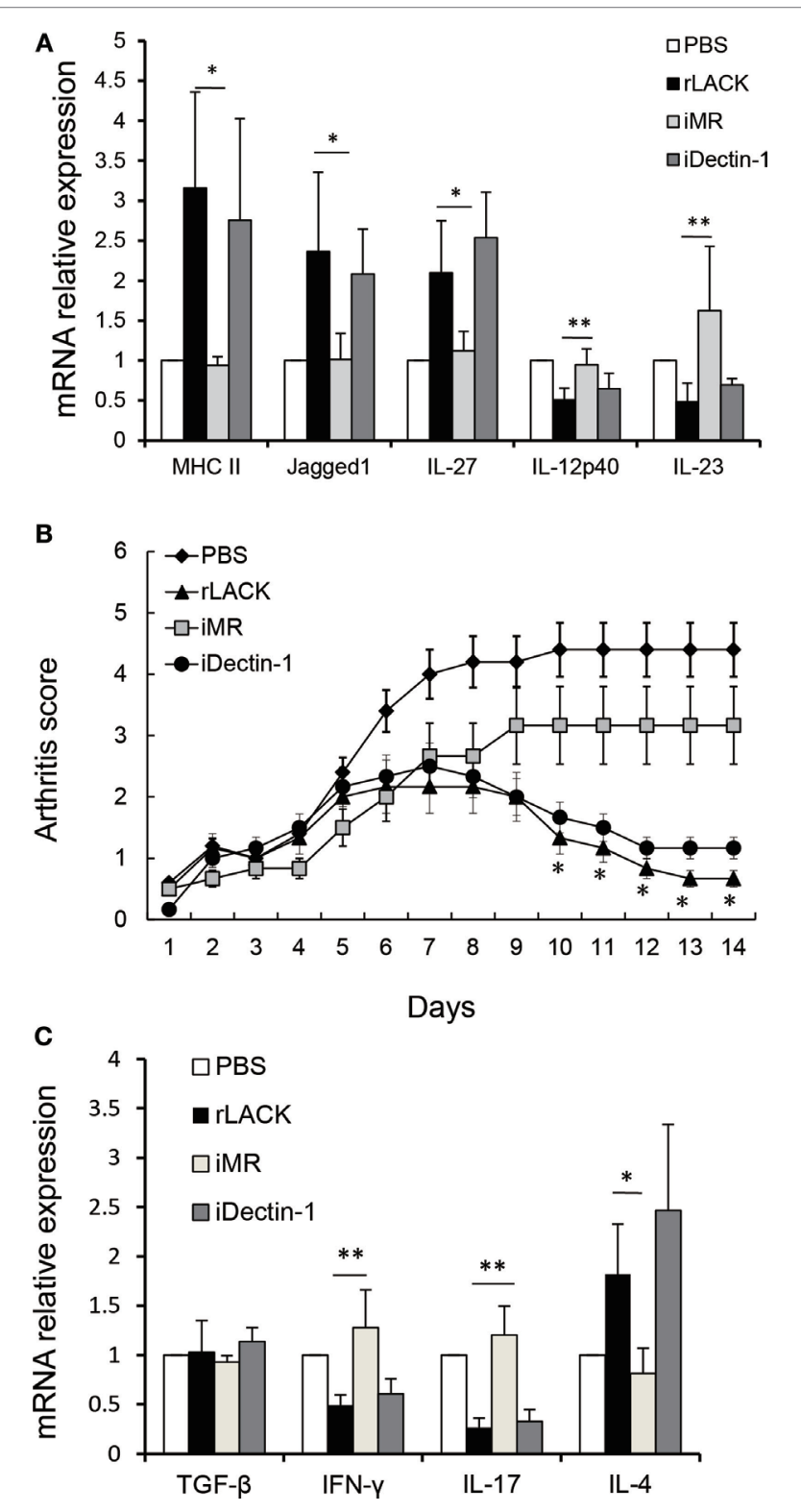

FIGURE 7 | The effect of anti-mannose receptor (MR) on LACK $_{156-173}$ epitope-stimulated dendritic cells (DCs) and rLACK-treated collagen antibody-induced arthritis (CAIA) mice. (A) Bone marrow-derived dendritic cells (BMDCs) obtained from BALB/c mice in 12-well plates were preincubated with medium containing the monoclonal antibodies (mAbs) against MR, dectin-1 $(10 \mu \mathrm{g} / \mathrm{ml})$ for $1 \mathrm{~h}$. Next, the cells were treated with rLACK $(100 \mu \mathrm{g} / \mu \mathrm{l})$ for $24 \mathrm{~h}$. The mRNA expression of cytokines and surface molecules of BMDCs were measured by quantitative real-time polymerase chain reaction. (B) The effect of targeting MR on the arthritis scores of CAIA mice treated with rLACK. The mAb against MR/Dectin-1 $(100 \mu \mathrm{g})$ was injected i.p. on day 4. Eight animals in each group. (C) Cytokines gene expression in the knee synovium of CAIA mice at day 14. Data are expressed as the mean \pm SEM for five animals in each group, combined from at least three independent experiments. ${ }^{*} p<0.05,{ }^{\star *} p<0.01$.

expression of MHC class II, CD40, and CD86; and decreased pro-inflammatory cytokine, co-stimulatory molecule (OX40L), adhesion molecule (ICAM-1), and TLR4 signaling pathway

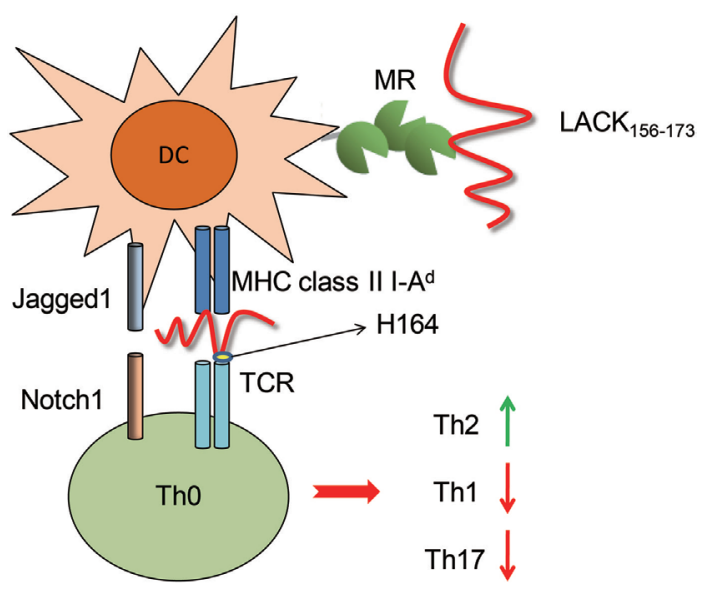

FIGURE 8 | The effect of the LACK $_{156-173}$ epitope on T cell polarization. The $L_{A C K_{156-173}}$ epitope regulates the subsets, maturation, and functions of dendritic cells through binding to mannose receptor (MR), resulting in upregulation of Jagged1. The $\mathrm{LACK}_{156-173}$ epitope is presented by major histocompatibility complex ( $\mathrm{MHC}$ ) class II I- $\mathrm{A}^{\mathrm{d}}$ molecules to $\mathrm{V} \beta 4^{+} \mathrm{N} \alpha 8^{+} \mathrm{T}$ cells and induces $\mathrm{T}$ helper (Th)2 cell polarization. Its effects are dependent on residue $\mathrm{H} 164$.

molecule expression among DCs. Based on our findings, we speculate that the differentiation, maturation, and functions of CD $11 \mathrm{c}^{+} \mathrm{DCs}$ are modulated by the $\mathrm{LACK}_{156-173}$ epitope. In addition, $\mathrm{LACK}_{156-173}$ epitope-matured DCs promoted Th2 responses and inhibited Th1 and Th17 responses, both in vivo and in vitro, via Jagged1. Therefore, we believe that the $\mathrm{LACK}_{156-173}$ epitope polarizes DCs and induces Th2 responses, mainly via Jagged1 signaling.

$\mathrm{T}$ cell activation requires recognition of an antigen that has been processed into a peptide, then loaded into a specialized groove in an MHC class II molecule for presentation to a TCR. The cells capable of processing and presenting antigen in this way include DCs, macrophages, and B cells. The $\mathrm{LACK}_{156-173}$ epitope is presented by MHC class II I- $\mathrm{A}^{\mathrm{d}}$ molecules, which are recognized by $\mathrm{V} \beta 4^{+} / \mathrm{V} \alpha 8^{+}$TCRs. So, the $\mathrm{LACK}_{156-173}$ epitope has therapeutic effects on autoimmune arthritis in BALB/c mice (I- $\left.A^{d}\right)$, but not DBA/1 (I-A $\left.{ }^{q}\right)$ mice. Meanwhile, H164 in the LACK $_{156-173}$ epitope seems to be important for the therapeutic effect. So, changes in this amino acid or modification of the $\mathrm{LACK}_{156-173}$ epitope make it can be identified by other MHC molecules and act on other organisms are our future research direction.

In another hand, we did not observe an effect of blocking $\mathrm{MHC}$ class II molecules on $\mathrm{LACK}_{156-173}$ epitope-induced cell activation. This phenomenon suggests that the MHC class II molecules are responsible only for antigen presentation, not for the capture of the $\mathrm{LACK}_{156-173}$ epitope. In addition, our results indicate that MR on DCs binds to rLACK and induces cell polarization. PRRs include TLRs, NLRs, RIG-I-like receptors, and C-type lectin receptors (CLRs). PRRs play important roles in determining the class of the adaptive immune response to a stimulus. MR (CD206), a member of the C-type lectin family, is highly expressed on macrophages and DCs (41). DCs drive Th2 differentiation via the activation of a combination of CLRs, including MR (42). MR does not appear 
to function as a canonical PRR capable of independent signal transduction, due to the lack of signaling motifs in its cytoplasmic tail. Signal transduction through MR has not been well studied. However, we confirmed that the $\mathrm{LACK}_{156-173}$ epitope regulates DCs by binding MR, through which it modulates $\mathrm{T}$ cell responses (Figure 8).

In summary, we confirmed that single microorganism epitope therapy with $\mathrm{LACK}_{156-173}$ did not cause inflammation and markedly ameliorated murine autoimmune arthritis. Our results demonstrate the dramatic therapeutic potential of the $\mathrm{LACK}_{156-173}$ epitope in autoimmune arthritis.

\section{ETHICS STATEMENT}

All animal experiments were carried out and approved according to the guidelines of the animal care and use committee at Harbin Medical University.

\section{REFERENCES}

1. Mellado M, Martínez-Muñoz L, Cascio G, Lucas P, Pablos JL, Rodríguez-Frade JM. $\mathrm{T}$ cell migration in rheumatoid arthritis. Front Immunol (2015) 6:384. doi:10.3389/fimmu.2015.00384

2. McInnes IB, Buckley CD, Isaacs JD. Cytokines in rheumatoid arthritis shaping the immunological landscape. Nat Rev Rheumatol (2016) 12:63-8. doi:10.1038/nrrheum.2015.171

3. Lamacchia C, Palmer G, Seemayer CA, Talabot-Ayer D, Gabay C. Enhanced Th1 and Th17 responses and arthritis severity in mice with a deficiency of myeloid cell-specific interleukin-1 receptor antagonist. Arthritis Rheum (2010) 62:452-62. doi:10.1002/art.27235

4. Nie H, Zheng Y, Li R, Guo TB, He D, Fang L, et al. Phosphorylation of FOXP3 controls regulatory $\mathrm{T}$ cell function and is inhibited by TNF-alpha in rheumatoid arthritis. Nat Med (2013) 19:322-8. doi:10.1038/nm.3085

5. Apaer S, Tuxun T, Ma HZ, Zhang H, Aierken A, Aini A, et al. Parasitic infection as a potential therapeutic tool against rheumatoid arthritis. Exp Ther Med (2016) 12:2359-66. doi:10.3892/etm.2016.3660

6. Wu Z, Nagano I, Asano K, Takahashi Y. Infection of non-encapsulated species of Trichinella ameliorates experimental autoimmune encephalomyelitis involving suppression of Th17 and Th1 response. Parasitol Res (2010) 107:1173-88. doi:10.1007/s00436-010-1985-9

7. Sofronic-Milosavljevic LJ, Radovic I, Ilic N, Majstorovic I, Cvetkovic J, Gruden-Movsesijan A. Application of dendritic cells stimulated with Trichinella spiralis excretory-secretory antigens alleviates experimental autoimmune encephalomyelitis. Med Microbiol Immunol (2013) 202:239-49. doi:10.1007/ s00430-012-0286-6

8. Motomura Y, Wang H, Deng Y, El-Sharkawy RT, Verdu EF, Khan WI. Helminth antigen-based strategy to ameliorate inflammation in an experimental model of colitis. Clin Exp Immunol (2009) 15:588-95. doi:10.1111/ j.1365-2249.2008.03805.x

9. Smith P, Mangan NE, Walsh CM, Fallon RE, McKenzie AN, van Rooijen N, et al. Infection with a helminth parasite prevents experimental colitis via a macrophage-mediated mechanism. J Immunol (2007) 178:4557-66. doi:10.4049/ jimmunol.178.7.4557

10. Sandborn WJ, Elliott DE, Weinstock J, Summers RW, Landry-Wheeler A, Silver N, et al. Randomised clinical trial: the safety and tolerability of Trichuris suis ova in patients with Crohn's disease. Aliment Pharmacol Ther (2013) 38:255-63. doi:10.1111/apt.12366

11. Hübner MP, Stocker JT, Mitre E. Inhibition of type 1 diabetes in filariainfected non-obese diabetic mice is associated with a T helper type 2 shift and induction of FoxP3+ regulatory T cells. Immunology (2009) 127:512-22. doi:10.1111/j.1365-2567.2008.02958.x

12. Shor DB, Shoenfeld Y. Autoimmunity: will worms cure rheumatoid arthritis? Nat Rev Rheumatol (2013) 9:138-40. doi:10.1038/nrrheum.2013.3

\section{AUTHOR CONTRIBUTIONS}

FY and YL conceived and designed the experiments. FY, XF, and $\mathrm{HH}$ performed all experiments and analyzed the data. FY, XF, $\mathrm{HH}, \mathrm{QD}, \mathrm{HL}$, and YL wrote the paper and edited the manuscript. All authors read and approved the final manuscript.

\section{ACKNOWLEDGMENTS}

We would like to thank Editage (www.editage.com) for English language editing.

\section{FUNDING}

This study was supported by grants from the National Natural Science Foundation of China (grant numbers 81373202 and 30972739) and the National High Technology Research and Development Program ofChina (grant number2015AA042401).

13. Versini M, Jeandel PY, Bashi T, Bizzaro G, Blank M, Shoenfeld Y. Unraveling the hygiene hypothesis of helminthes and autoimmunity: origins, pathophysiology, and clinical applications. BMC Med (2015) 13:81. doi:10.1186/s12916-0150306-7

14. Pérez-Jiménez E, Kochan G, Gherardi MM, Esteban M. MVA-LACK as a safe and efficient vector for vaccination against leishmaniasis. Microbes Infect (2006) 8:810-22. doi:10.1016/j.micinf.2005.10.004

15. Pfeiffer C, Stein J, Southwood S, Ketelaar H, Sette A, Bottomly K. Altered peptide ligands can control CD4 T lymphocyte differentiation in vivo. J Exp Med (1995) 181:1569-74. doi:10.1084/jem.181.4.1569

16. Pingel S, Launois P, Fowell DJ, Turck CW, Southwood S, Sette A, et al. Altered ligands reveal limited plasticity in the $\mathrm{T}$ cell response to a pathogenic epitope. J Exp Med (1999) 189:1111-20. doi:10.1084/jem.189.7.1111

17. Jensen KD, Sercarz EE, Gabaglia CR. Altered peptide ligands can modify the Th2 T cell response to the immunodominant 161-175 peptide of LACK (Leishmania homolog for the receptor of activated C kinase). Mol Immunol (2009) 46:366-74. doi:10.1016/j.molimm.2008.10.024

18. Reis e Sousa C. Dendritic cells in a mature age. Nat Rev Immunol (2006) 6:476-83. doi:10.1038/nri1845

19. Schlitzer A, Ginhoux F. Organization of the mouse and human DC network. Curr Opin Immunol (2014) 26:90-9. doi:10.1016/j.coi.2013.11.002

20. Liu F, Liang M, Cao S, Liu Q, Zhang Q, Li C, et al. Fusion with extracellular domain of cytotoxic T-lymphocyte-associated-antigen 4 leads to enhancement of immunogenicity of Hantaan virus DNA vaccines in C57BL/6 mice. Virol J (2011) 8:448. doi:10.1186/1743-422X-8-448

21. Mills KH. TLR-dependent T cell activation in autoimmunity. Nat Rev Immunol (2011) 11:807-22. doi:10.1038/nri3095

22. Kumar H, Kawai T, Akira S. Pathogen recognition by the innate immune system. Int Rev Immunol (2011) 30:16-34. doi:10.3109/08830185.2010.529976

23. Mildner A, Jung S. Development and function of dendritic cell subsets. Immunity (2014) 40:642-56. doi:10.1016/j.immuni.2014.04.016

24. Schraml BU, Reis e Sousa C. Defining dendritic cells. Curr Opin Immunol (2015) 32:13-20. doi:10.1016/j.coi.2014.11.001

25. Maldonado-López R, Moser M. Dendritic cell subsets and the regulation of Th1/Th2 responses. Semin Immunol (2001) 13:275-82. doi:10.1006/smim. 2001.0323

26. Moser M. Regulation of Th1/Th2 development by antigen-presenting cells in vivo. Immunobiology (2001) 204:551-7. doi:10.1078/0171-2985-00092

27. Tjota MY, Sperling AI. Distinct dendritic cell subsets actively induce Th2 polarization. Curr Opin Immunol (2014) 31:44-50. doi:10.1016/j.coi.2014.09.006

28. de Jong EC, Smits HH, Kapsenberg ML. Dendritic cell-mediated T cell polarization. Springer Semin Immunopathol (2005) 26:289-307. doi:10.1007/ s00281-004-0167-1

29. Mochizuki K, Xie F, He S, Tong Q, Liu Y, Mochizuki I, et al. Delta-like ligand 4 identifies a previously uncharacterized population of inflammatory dendritic 
cells that plays important roles in eliciting allogeneic $\mathrm{T}$ cell responses in mice. J Immunol (2013) 190:3772-82. doi:10.4049/jimmunol.1202820

30. Lin CL, Hsiao G, Wang CC, Lee YL. Imperatorin exerts antiallergic effects in Th2-mediated allergic asthma via induction of IL-10-producing regulatory T cells by modulating the function of dendritic cells. Pharmacol Res (2016) 110:111-21. doi:10.1016/j.phrs.2016.04.030

31. Damle SR, Martin RK, Cockburn CL, Lownik JC, Carlyon JA, Smith AD, et al. ADAM10 and Notch1 on murine dendritic cells control the development of type 2 immunity and IgE production. Allergy (2018) 73(1):125-36. doi:10.1111/all.13261

32. Walsh KP, Mills KH. Dendritic cells and other innate determinants of T helper cell polarisation. Trends Immunol (2013) 34:521-30. doi:10.1016/j. it.2013.07.006

33. Wammes LJ, Mpairwe H, Elliott AM, Yazdanbakhsh M. Helminth therapy or elimination: epidemiological, immunological, and clinical considerations. Lancet Infect Dis (2014) 14:1150-62. doi:10.1016/S1473-3099(14)70771-6

34. Osada Y, Shimizu S, Kumagai T, Yamada S, Kanazawa T. Schistosoma mansoni infection reduces severity of collagen-induced arthritis via down-regulation of pro-inflammatory mediators. Int J Parasitol (2009) 39:457-64. doi:10.1016/j. ijpara.2008.08.007

35. McInnes IB, Leung BP, Harnett M, Gracie JA, Liew FY, Harnett W. A novel therapeutic approach targeting articular inflammation using the filarial nematode-derived phosphorylcholine-containing glycoprotein ES-62. J Immunol (2003) 171:2127-33. doi:10.4049/jimmunol.171.4.2127

36. Rodgers DT, Pineda MA, McGrath MA, Al-Riyami L, Harnett W, Harnett MM. Protection against collagen-induced arthritis in mice afforded by the parasitic worm product, ES-62, is associated with restoration of the levels of interleukin-10-producing B cells and reduced plasma cell infiltration of the joints. Immunology (2014) 141:457-66. doi:10.1111/imm.12208
37. Wong C, Goldstein DR. Impact of aging on antigen presentation cell function of dendritic cells. Curr Opin Immunol (2013) 25:535-41. doi:10.1016/j. coi.2013.05.016

38. Coutant F, Miossec P. Altered dendritic cell functions in autoimmune diseases: distinct and overlapping profiles. Nat Rev Rheumatol (2016) 12:703-15. doi:10.1038/nrrheum.2016.147

39. Schmitt N, Ueno H. Regulation of human helper $\mathrm{T}$ cell subset differentiation by cytokines. Curr Opin Immunol (2015) 34:130-6. doi:10.1016/j.coi.2015. 03.007

40. Gutcher I, Becher B. APC-derived cytokines and T cell polarization in autoimmune inflammation. J Clin Invest (2007) 117:1119-27. doi:10.1172/ JCI31720

41. Rajaram MV, Ni B, Dodd CE, Schlesinger LS. Macrophage immunoregulatory pathways in tuberculosis. Semin Immunol (2014) 26:471-85. doi:10.1016/j. smim.2014.09.010

42. Wills-Karp M. Allergen-specific pattern recognition receptor pathways. Curr Opin Immunol (2010) 22:777-82. doi:10.1016/j.coi.2010.10.011

Conflict of Interest Statement: The authors declare that the research was conducted in the absence of any commercial or financial relationships that could be construed as a potential conflict of interest.

Copyright $\odot 2018$ Yang, Fan, Huang, Dang, Lei and Li. This is an open-access article distributed under the terms of the Creative Commons Attribution License (CC BY). The use, distribution or reproduction in other forums is permitted, provided the original author(s) and the copyright owner are credited and that the original publication in this journal is cited, in accordance with accepted academic practice. No use, distribution or reproduction is permitted which does not comply with these terms. 